\title{
Astrocytes in heavy metal neurotoxicity and neurodegeneration
}

DOI:

10.1016/j.brainres.2020.147234

\section{Document Version}

Accepted author manuscript

Link to publication record in Manchester Research Explorer

\section{Citation for published version (APA):}

Li, B., Xia, M., Zorec, R., Parpura, V., \& Verkhratsky, A. (2021). Astrocytes in heavy metal neurotoxicity and neurodegeneration. Brain research, 1752, 147234. https://doi.org/10.1016/j.brainres.2020.147234

\section{Published in:}

Brain research

\section{Citing this paper}

Please note that where the full-text provided on Manchester Research Explorer is the Author Accepted Manuscript or Proof version this may differ from the final Published version. If citing, it is advised that you check and use the publisher's definitive version.

\section{General rights}

Copyright and moral rights for the publications made accessible in the Research Explorer are retained by the authors and/or other copyright owners and it is a condition of accessing publications that users recognise and abide by the legal requirements associated with these rights.

\section{Takedown policy}

If you believe that this document breaches copyright please refer to the University of Manchester's Takedown Procedures [http://man.ac.uk/04Y6Bo] or contact uml.scholarlycommunications@manchester.ac.uk providing relevant details, so we can investigate your claim.

\section{OPEN ACCESS}




\section{Astrocytes in Heavy Metal Neurotoxicity and Neurodegeneration}

\section{Baoman $\mathrm{Li}^{1}$, Maosheng $\mathrm{Xia}^{2}$, Robert Zorec ${ }^{3}$, Vladimir Parpura ${ }^{4}$ and Alexei Verkhratsky ${ }^{1,5,6^{*}}$}

${ }^{1}$ Practical Teaching Centre, School of Forensic Medicine, China Medical University, Shenyang, People's Republic of China.

${ }^{2}$ Department of Orthopaedics, The First Hospital, China Medical University, Shenyang, People's Republic of China.

${ }^{3}$ Celica BIOMEDICAL, Tehnološki Park 24, 1000 Ljubljana, Slovenia; Laboratory of Neuroendocrinology-Molecular Cell Physiology, Institute of Pathophysiology, Faculty of Medicine, University of Ljubljana, Zaloška 4, 1000 Ljubljana, Slovenia.

${ }^{4}$ Department of Neurobiology, The University of Alabama at Birmingham, Birmingham, AL 35294, USA.

${ }^{5}$ Faculty of Biology, Medicine and Health, The University of Manchester, Manchester, UK.

${ }^{6}$ Achucarro Center for Neuroscience, IKERBASQUE, Basque Foundation for Science, 48011 Bilbao.

Corresponding authors:

Prof. Baoman Li, Ph.D., M.D.

Practical Teaching Center, School of Forensic Medicine, China Medical University

No. 77, Puhe Street, Shenbei District, Shenyang, P.R. China

Postcode: 110177

Phone: 86(24)31939437

Fax: 86(24) 83282772

Email: bmli@cmu.edu.cn

OR

Prof. Alexei Verkhratsky, Ph.D., M.D.

Faculty of Biology, Medicine and Health

The University of Manchester

Manchester M13 9PT, UK

Email: Alexej.Verkhratsky@manchester.ac.uk 


\begin{abstract}
With the industrial development and progressive increase in environmental pollution, the mankind overexposure to heavy metals emerges as a pressing public health issue. Excessive intake of heavy metals, such as arsenic (As), manganese (Mn), mercury $(\mathrm{Hg})$, aluminium $(\mathrm{Al})$, lead $(\mathrm{Pb})$, nickel $(\mathrm{Ni})$, bismuth $(\mathrm{Bi})$, cadmium $(\mathrm{Cd})$, copper $(\mathrm{Cu})$, zinc $(\mathrm{Zn})$, and iron $(\mathrm{Fe})$, is neurotoxic and it promotes neurodegeneration. Astrocytes are primary homeostatic cells in the central nervous system. They protect neurons against all types of insults, in particular by accumulating heavy metals. However, this makes astrocytes the main target for heavy metals neurotoxicity. Intake of heavy metals affects astroglial homeostatic and neuroprotective cascades including glutamate/GABA-glutamine shuttle, antioxidative machinery and energy metabolism. Deficits in these astroglial pathways facilitate or even instigate neurodegeneration. In this review, we provide a concise outlook on heavy metal-induced astrogliopathies and their association with major neurodegenerative disorders. In particular, we focus on astroglial mechanisms of iron-induced neurotoxicity. Iron deposits in the brain are detected in main neurodegenerative diseases, such as Alzheimer's disease, Parkinson's disease and amyotrophic lateral sclerosis. Accumulation of iron in the brain is associated with motor and cognitive impairments and iron-induced histopathological manifestations may be considered as the potential diagnostic biomarker of neurodegenerative diseases. Effective management of heavy metal neurotoxicity can be regarded as a potential strategy to prevent or retard neurodegenerative pathologies.
\end{abstract}

Keywords: heavy metals; astrocytes; neurotoxicity; neurodegeneration; glutamate 


\section{Highlights}

Astrocytes protect neurones against neurotoxicity induced by heavy metals.

Astrocytes are the main target for heavy metal neurotoxicity.

Heavy metals affect astrocytic plasmalemmal glutamate transporters resulting in neurodegeneration.

Iron overload triggers neurodegeneration by inducing astrogliopathies.

Over-intake of heavy metal(s) including iatrogenic sources should be carefully managed. 


\section{Introduction}

Humans are exposed to pathological load of metals through contaminated food, contaminated environment (water and air) or through occupational exposure (Liu et al., 2019; Bai et al., 2019; Jan et al., 2015; Qu et al., 2012; Sarah et al., 2019); excess of metals in the body often results in neurotoxicity and associated neurological disorders. Excessive accumulation of metallic elements, such as arsenic (As), manganese $(\mathrm{Mn})$, mercury $(\mathrm{Hg})$, lead $(\mathrm{Pb})$, aluminium $(\mathrm{Al})$, nickel $(\mathrm{Ni})$, bismuth $(\mathrm{Bi})$, cadmium $(\mathrm{Cd})$, zinc $(\mathrm{Zn})$, copper $(\mathrm{Cu})$ and iron $(\mathrm{Fe})$, are known to be neurotoxic and increase the risk for neurodegenerative diseases, particularly of Alzheimer's disease (AD) and Parkinson's disease (PD) (Supino-Viterbo et al.,1977; Kirkley et al., 2017; Pamphlett and Kum, 2018; Rahman et al., 2019; Ijomone et al., 2020; Sudhakaran et al., 2019).

Metal poisioning has been recognized throughout history of mankind. Lead toxicity, which results in memory impairments, has been known since antiquity (Waldron, 1973), while adverse effects caused by water drinking from lead-furnished water pipes have been proposed as a biological background for the fall of the Roman empire (Nriagu, 1983). The first clinical description of an acute $\mathrm{Pb}$ poisoning that included paralysis was produced by Nicander of Colophon in the $2^{\text {nd }}$ century BC (Waldron, 1973). Chronic mercury poisoning caused erethism mercurialis (also known as mad hatter syndrome in the $17^{\text {th }}$ century France) characterised with psychotic symptoms and impaired memory (O'Carroll et al., 1995). Mercury poisoning resulting in neurodegeneration was observed on the shores of Minamata bay, which gave the name to Minamata disease (McAlpine and Araki, 1958). Today, metal pollution of food chains rise significant concerns (Rahman et al. 2014; Wang et al. 2017; Wu et al., 2013). In particular iron oxides are ubiquitous in both natural and industrial environments, with iron being fundamental for metabolic and physiological activities. At the same time, a loss of iron homeostasis or an excessive load with iron (resulting from dietary intake or from medical procedures such as iron implants or usage of iron oxide nanoparticles) is harmful for health (Okereafor et al., 2020; Li Y. et al., 2020; Vogel et al., 2016; Xia et al., 2020).

Metal toxicity affects the brain development and impairs cognition, memory and learning in humans and in animal models (Hussien et al., 2018; Mason et al., 2014). Clinically, chronic superfluous intake of metals usually instigate neurological symptoms such as dizziness, headaches, motor impairments and cognitive and memory deficits (Wu et al., 2013; Peres et al., 2015). These symptoms may also signal the beginning of a neurodegenerative process (Bauer et al., 2015; Buckner, 2004), which results from integration of multiple factors, including genetic background, adverse lifestyle and environmental pressures (Eid et al., 2019). Levels of some heavy metals such as $\mathrm{Mn}, \mathrm{Hg}$ and $\mathrm{Cd}$ are increased in the plasma and cerebrospinal fluid (CSF) of AD-patients (Gerhardsson et al., 2008; Basun et al., 1991). Heavy metals have been reported to increase the presence of AD-relevant 
proteins, such as $\beta$-amyloid, Tau and ApoE4 both in vitro and in vivo (Moyano et al., 2020; Godfrey et al., 2003; Olivieri et al., 2000; Al Kahtani et al., 2020). In addition, heavy metals elevate $\beta$-amyloid load by decreasing the clearance of $\beta$-amyloid from the brain (Gu et al., 2011; Kim et al., 2014). Recent and growing evidence reports that disturbed iron homeostasis is an early presentation in the AD (Kim et al., 2018; Mandel et al., 2007), while the level of iron in the hippocampus and cortex of AD-patients is increased compared with healthy subjects (Corrigan et al., 1993; Gu et al., 1998). Abnormal level of iron causes the suppression of function of several enzymes that require iron as a co-modulator, forming toxic oxidizing species, and stimulating $\beta$-amyloidogenesis (Qian and Wang, 1998). Several common genetic polymorphisms that cause the aberrant iron homeostasis are frequently associated with AD (Crespo et al., 2014; Nandar and Connor, 2011), although the mechanistic links remain unclear. Environmental overexposure to $\mathrm{Pb}$ is another well known risk factor for AD (Chin-Chan et al., 2015). In animal models, the oral intake of excessive $\mathrm{Pb}$ increases the cerebral level of $\beta$-amyloid, as well as levels of the pro-inflammatory interleukin-1 (IL-1) and tumour necrosis factor $\alpha$ (TNF- $\alpha$ ); these changes were associated with the impaired cognitive capacity (Li et al., 2014a).

The over-intake of heavy metals represents a high risk for PD, resulting from the loss of dopaminergic neurones in the substantia nigra (Mu et al., 2020). Significant association between PD and exposure to $\mathrm{Cu}, \mathrm{Mn}$ and $\mathrm{Fe}$ in workers with more than 20 years of occupational history has been identified in a population-based case-control study in Detroit (Gorell et al., 1997; Powers et al., 2003; Fukushima et al., 2013). In animal models, chronic exposure to $\mathrm{Mn}, \mathrm{Cd}$ or $\mathrm{Hg}$ triggers neuroinflammation and impairs the function of mitochondria, thus, producing the PD-like neurological symptoms (Hammond et al., 2020; Zhang et al., 2017; Qu et al., 2013; Han et al., 2017). Substantia nigra pars compacta has the highest levels of iron in the human brain and, hence, iron is considered as a risk factor for PD (Jiang et al., 2019). In PD patients, iron levels are increased in parietal and prefrontal cortices; increase in iron can be a predictor of poor cognitive outcome, and its elevation in the putamen predicts poorer motor function (Thomas et al., 2020). Overload with iron triggers production of reactive oxygen species (ROS) and pro-inflammatory factors, thus, further exacerbating neuroinflammation and brain pathology (Bjørklund et al., 2019; Heneka et al., 2010; Neal and Richardson, 2017).

Astrocytes are the homeostatic cells of the central nervous system (CNS); in particular they are fundamental for the ionostasis of the nervous tissue (Verkhratsky and Nedergaard, 2018). Through an extended family of plasmalemmal transporters astrocytes control concentrations of ions in the interstitial fluids (Verkhratsky and Rose, 2020; Rose and Verkhratsky, 2016). In particular, astroglial transporters remove excess of heavy metals from the brain parenchyma, thus, protecting neurones against toxicity. Of note, microglial cells also contribute to this protection (Zheng et al., 2010). Accumulation of heavy metals, however, damages astrocytes and affects their homoeostatic and neuroprotective cascades, of which most important are associated 
with glutamate-glutamine transport and anti-oxidative support.

\section{Astrocytes glutamate homoeostatic cascade as the main target for metal neurotoxicity}

\subsection{The homeostasis of glutamate}

Glutamate and $\gamma$-aminobutoric acid (GABA) are respectively major excitatory and inhibitory neurotransmitters in the brain. Both share the same biosynthetic pathway deriving from glucose, which makes catabolism of them strictly astroglia-dependent. Astrocytes are the only cells in the brain capable of producing de novo glutamate (and by proxy, GABA) from glucose (Hertz et al., 1999). The key enzymes for this process are pyruvate carboxylase (which produce $\alpha$-ketoglutarate) and glutamine synthetase (which converts glutamate to glutamine); both these enzymes are expressed exclusively in astrocytes (Norenberg and Martinez-Hernandez, 1979; Schousboe et al., 2014; Shank et al.,1985; Rose et al., 2013). Glutamine is a non-toxic precursor for glutamate and hence it can be safely transported to neurones where it is converted (by phosphate-activated glutaminase) to glutamate in excitatory terminals (Hertz, 2013); in inhibitory terminals glutamate is converted to GABA (Rose et al., 2013). This final conversion is mediated by glutamate decarboxylase (Bak et al., 2006). These enzymatic cascades are coordinated with astroglial plasmalemmal transporters and operate in concert as an astroglial glutamate/GABA-glutamine shuttle, which controls extracellular levels of glutamate and supplies neurones with glutamine. Control over extracellular glutamate is of paramount importance to prevent glutamate excitotoxicity which appears as the major neuronal killer in conditions of brain pathology (Choi, 1992).

Glutamate, secreted during neurotransmission is taken up by astrocytes via sodium-dependent excitatory amino acid transporters 1 and 2 (EAAT1/SLC1A3 and EAAT2/SLC1A2, also known, in rodent experiments as glutamate-aspartate transporter GLAST and glutamate transporter-1, GLT1). These transporters are almost exclusively astroglial with some variations between brain regions (Danbolt, 2001; Zhou and Danbolt, 2013); activity of these transporters is regulated by transmembrane $\mathrm{Na}^{+}$gradients (Kirischuk et al., 2007). Expression of glutamate transporters varies across the brain; the EAAT1 dominates cerebellum, retina and circumventricular organs (Lehre and Danbolt, 1998; Berger and Hediger, 2000; Rauen et al., 1996), whereas EAAT2 demonstrates higher expression in other regions. The average density of astroglial transporters is exceptionally high with EAAT1 reaching $4700 / \mu^{2}$ in Bergmann glia and $2300 / \mu \mathrm{m}^{2}$ in astrocytes of the CA1 hippocampal area; the density of EAAT2 is $\sim 8500 / \mu \mathrm{m}^{2}$ in the hippocampus and $\sim 740 / \mu \mathrm{m}^{2}$ in the cerebellum (Lehre and Danbolt, 1998). At the ultrastructural level most of transporters are concentrated at the perisynaptic astroglial processes (Chaudhry et al., 1995). After entering astrocytes, glutamate is mainly converted to glutamine by glutamine synthetase; glutamine is subsequently transported to neurones. This transport is mediated by 
sodium-coupled neutral amino acid transporters; astroglial SNAT3/SLC38A3 and SNAT5/SLC38A5 mediate export of glutamine, while neuronal SNAT1/SLC38A1, SNAT2/SLC38A2 and SNAT4/SLC38A4 are responsible for glutamine import (Verkhratsky and Nedergaard, 2018; Verkhratsky and Rose, 2020). Proper functional activity of glutamate/GABA-glutamine shuttle is critical for neurotransmission and changes in expression or activity of its components lead to various pathologies including neurodegeneration (Rose et al., 2013).

\subsection{Astrocytes define glutamate excitotoxicity}

In pathological conditions, decreased expression and/or inefficiency of EAATs results in the increased level of extracellular glutamate with the subsequent excitotoxicity (Olloquequi et al., 2018). Mechanistically, an excess of extracellular glutamate depolarises neurones, which leads to opening of $\mathrm{Ca}^{2+}$ permeable NMDA receptors and voltage-gated $\mathrm{Ca}^{2+}$ channels, subsequently causing an overload of the cytoplasm with $\mathrm{Ca}^{2+}$. This pathological $\mathrm{Ca}^{2+}$ signalling initiates oxidative stress, mitochondrial damage, massive activation of proteolytic enzymes etc., ultimately instigating necrotic or apoptotic cell death (Peng and Jou, 2010; Martinez-Ruiz et al., 2011; Dzialo et al., 2013; Piña-Crespo et al., 2014). Excitotoxicity contributes to neurodegenerative diseases. For example, neurotoxic $\beta$-amyloid may increase extracellular glutamate, thus, triggering pathological $\mathrm{Ca}^{2+}$ signalling (Busche et al., 2008; Kuchibhotla et al., 2008). Pharmacological inhibition of NMDA receptors with memantine was reported to normalise cognitive performance, decrease $\beta$-amyloid load and plaque deposition in clinical and animal studies of AD (Danysz and Parsons, 2012). In PD, the expression and function of EAAT1 is significantly decreased, thus, instigating excitotoxicity and subsequent death of dopaminergic neurones (Sominsky et al., 2015). Aberrant $\mathrm{Ca}^{2+}$ signalling and failed $\left[\mathrm{Ca}^{2+}\right]_{\mathrm{i}}$ homeostasis induced by excitotoxicity can lead to the malfunction of mitochondrial bioenergetics and the increased level of ROS, damaging dopaminergic neurones (Cieri et al., 2017; Surmeier et al., 2017). Excitotoxicity is the key pathogenetic step in amyotrophic lateral sclerosis (ALS); in this pathology excessive glutamate in the extracellular space results from substantial down-regulation of astroglial EAAT2 transporters that results in the insufficient glutamate uptake (Mathis et al., 2017). Treatment with riluzole (2-amino-6-trifluoromethoxy benzothiazole; the only partially effective monotherapy in ALS) counteracts glutamate excitotoxicity by inhibiting glutamate release from presynaptic terminals and up-regulating expression of astroglial plasmalemmal glutamate transporters (Zarei et al., 2015; Carbone et al., 2012).

\subsection{Heavy metals affect astroglial plasmalemmal glutamate transporters, hence, instigating neurodegeneration}

In the brain, $\mathrm{Mn}$ ions $\left(\mathrm{Mn}^{2+} / \mathrm{Mn}^{3+}\right)$ cross the blood-brain barrier (BBB) and are preferentially accumulated by astrocytes through the plasmalemmal divalent metal transporter-1 (DMT1) and by binding to and internalising with transferrin receptor 
(TFR) (Fitsanakis et al., 2006 and 2007; Erikson and Aschner, 2006). The main pathological effect of $\mathrm{Mn}$ is the disturbance of the glutamate/GABA-glutamine shuttle at multiple levels. Excess of intra-astroglial Mn decreases the activity of glutamine synthetase and down-regulates expression of EAAT1 and EAAT2 (Deng et al., 2012; Lee et al., 2013; Johnson et al., 2018). Suppression of plasmalemmal glutamate transporters expression in astrocytes is mediated by a transcription factor Yin Yang 1 (YY1) activated by the Mn-sensitive nuclear factor kappa-light-chain-enhancer of activated B cells (NF- $\mathrm{kB}$ ) cascade (Karki et al., 2014; Karki et al., 2015). As a result, dysfunctional glutamine catabolism and elevated extracellular glutamate induce excitotoxicity, neuronal damage and contribute to neurodegenerative process (Sidoryk-Wegrzynowicz et al., 2013; Miyata et al., 1983; Lu et al., 2018). Astrocytic plasmalemmal glutamate transporters are similarly vulnerable to other heavy metals, such as $\mathrm{Pb}$ and $\mathrm{Hg}$, both of which dysregulate glutamate homeostasis by inhibiting the expression and/or function of astroglial plasmalemmal glutamate transporters (Struzynska et al., 2005). Hippocampal structures seem to be more sensitive to $\mathrm{Pb}$, which evokes deficits in cognition and learning (Gilbert et al., 1999). Additionally, the overexposure to $\mathrm{Hg}$ inhibits the mRNA expression and the related functions of EAATs by stimulating astrocytic ROS (Allen et al., 2001; Mutkus et al., 2005). Similarly, arsenite inhibits glutamate clearance by suppressing expression of glutamine synthetase, EAAT-1 and EAAT2 in astrocytes; impairment of glutamate/GABA-glutamine shuttle represents a leading mechanism of As-induced neurotoxicity (Zhao et al., 2012).

\section{Astroglial zink and neurodegeneration}

Zinc is the second most abundant trace element in mammalian tissues and is indispensable for normal brain functions (Paoletti et al., 2009). Zinc dyshomeostasis is associated with several neurological disorders including depression, schizophrenia, AD, ALS and aging-related cognitive decline (Levenson and Tassabehji, 2007; Grabruckeretal., 2011; Adlard et al., 2014). Astrocytes can rapidly accumulate zinc through zinc-transporters $(\mathrm{ZnT})$ including $\mathrm{Zn}$-regulated and iron-regulated transporter proteins 14 (ZIP14) and ZnT3, thus, protecting neurones against Zn toxicity (Nolte et al., 2004; Bishop et al., 2010; Sun et al., 2012). Over-accumulation of Zn in the brain can trigger the aggregation of $\beta$-amyloid and formation of associated senile plaques, thus, contributing to the AD-type neurodegeneration (Hancock et al., 2014). Chronic exposure to $\mathrm{Zn}$ can promote the deposition of $\beta$-amyloid and an increase in S100A6 (an acidic $\mathrm{Ca}^{2+} / \mathrm{Zn}^{2+}$-binding protein) in APP/PS1 transgenic mice; however, exogenous S100A6 is capable of decreasin the aggregation of $\beta$-amyloid by buffering/binding $\mathrm{Zn}$ in astrocytes and attenuating the AD-related cognitive deficits (Tian et al., 2019).

\section{Iron in brain pathology: The role of glia}

Iron is the most abundant metal in the brain responsible for normal physiological 
functions and developmental processes (Ashraf et al., 2018). The level of iron is gradually increasing with ageing in the substantia nigra, in basal ganglia and cortex (Ramos et al., 2014), albeit the reason for this specific accumulation remains unknown. Excessive accumulation of iron in the brain has been regarded as the major high risk for the neurodegenerative diseases, including AD, PD and ALS (Belaidi and Bush, 2016; Liu et al., 2019; Kwakye et al., 2019; Stephenson et al., 2014).

In physiological conditions, iron contributes to oxygen transportation, mitochondrial respiration, myelin formation, DNA replication and cell signalling (Dev and Babitt, 2017). Homeostatic iron control is fundamental for human health, because both the deficiency and overload of iron are harmful. Iron deficiency is one of the most abundant nutritional deficient diseases. The most common disease is the iron deficiency anaemia, which occurs in infants, adolescents, pregnant women and it presents as secondary symptoms of many clinical conditions, such as gastrectomy and inflammatory bowel disease (Wan et al., 2019). In contrast, iron overload usually emerges in patients with chronic liver or kidney diseases, or results from the iatrogenic treatments including excessive therapeutic supplementation and haemodialysis, or caused by the excessive dietary intake and nutritional supplements (Rostoker and Vaziri, 2017a and 2017b; Lu et al., 2020; Ceylan et al., 2019).

\subsection{Iron transport and homeostasis in the brain}

Iron from food comes in two forms, the heme iron and non-heme iron, with the latter accounting for $90 \%$ of the total iron. Non-heme iron is mainly taken in the brush border of duodenal enterocytes (Zhang Y et al., 2017), the cytochrome b of the cellular membranes of these cells reduces $\mathrm{Fe}^{3+}$ to $\mathrm{Fe}^{2+}$, while the latter is transported by plasmalemmal DMT1. The heme iron absorption proceeds through the uptake of the heme carrier protein 1 (HCP-1) (Shayeghi et al., 2005; Krishnamurthy et al., 2007), while the export of the intracellular iron occurs through the ferroportin1 (Fpn1) (Troadec et al., 2010). After $\mathrm{Fe}^{2+}$ comes into the blood circulation, it is oxidized to $\mathrm{Fe}^{3+}$ by the ferroxidases including hephaestin (HEPH) and ceruloplasmin (CP); $\mathrm{Fe}^{3+}$ is transported by binding to transferrin (Tf) (Chen et al., 2004; Hellman and Gitlin, 2002). Several pathways translocate iron across the BBB: (i) $\mathrm{TF}-$ bound $\mathrm{Fe}^{3+}$ by virtue of TFR mainly crosses the luminal membrane of the endothelium; (ii) TF-bound $\mathrm{Fe}^{3+}$ can also be transported by transcytosis; (iii) $\mathrm{Fe}^{2+}$ is mainly transported by DMT1 localised on the luminal membrane of endothelial cells; (iv) Fpn1 is responsible for the export of iron from endothelial cells to the extracellular space of the brain parenchyma (Jiang et al., 2019; Qian and Ke, 2019). After entering the brain, iron binds to TF, which is mainly secreted by epithelial cells of the choroid plexus (Leitner \& Connor, 2012). Compared with the peripheral tissues, the concentration of non-transferrin-bound iron (NTBI) is higher in the CSF and interstitial fluid (IF), because citrate and ascorbate secreted by astrocytes help to maintain iron in the reduced $\mathrm{Fe}^{2+}$ status (Knutson, 2019; Ji and Kosman, 2015). The glia limitans vascularis formed by astroglial endfeet covering blood vessels plays a crucial role in 
regulating iron homeostasis in the brain through expressing DMT1 to uptake $\mathrm{Fe}^{2+}$ (Dringen et al., 2007; Simpson et al., 2015). Early immunohistochemical studies failed to detect TFR or DMT1 is in the adult mouse astrocytes (Moos, 1996; Moos \& Morgan, 2004). Recently, however, expression of TFR and DMT1 have been demonstrated in astrocytes in vitro as well as in vivo (Lis et al., 2004; Pelizzoni et al., 2012; Rathore, Redensek, \& David, 2012; Urrutia et al., 2013; Zarruk et al., 2015; Xu et al., 2019; Qian et al., 1999; Hoepken et al., 2004). Therefore , astrocytes are able to accumulate $\mathrm{Fe}^{3+}$ and $\mathrm{Fe}^{2+}$ by the TFR and DMT1 pathways, respectively (Tulpule et al., 2010). In addition, the uptake of NTBI into astrocytes can be mediated by ZIP14 (Bishop et al., 2010).

\subsection{Iron overload and neurodegeneration}

Patients with PD have higher iron content in the substantia nigra pars compacta as seen by magnetic resonance imaging (MRI) (Ulla et al., 2013; Wieler et al., 2015).

Similarly, iron is accumulated in neurones of 1-methyl-4-phenyl-1,2,3,6-tetrahydropyridine (MPTP)-induced monkey and mouse models of PD (He et al., 2003; Wang et al., 2009; Jiang et al., 2003; Youdim et al., 2003). Increase in iron concentration in dopaminergic neurons aggravates the oxidative stress in which iron reacts with $\mathrm{H}_{2} \mathrm{O}_{2}$ produced by dopamine metabolism with subseqeunet generation of $\mathrm{OH}^{-}$radicals that can damage proteins, nucleic acids, and membrane phospholipids (Dias et al., 2013; Melis et al., 2013). Furthermore, ROS can induce additional release of iron from mitochondria, thus, further stimulating production of ROS (Ward et al., 2014). This vicious circle and excessive accumulation of ROS are arguably instrumental in instigating cellular death by oxidizing proteins (Melis et al., 2013; Ward et al., 2014). This type of cell death is known as ferroptosis, as the overload with iron causes the overwhelming oxidative damage and the lethal increase in lipid hydroperoxides (Reed and Pellecchia, 2012).

Abnormal iron accumulation is also considered as an early hallmark for AD. Iron elevation in the AD brain was first reported in 1953 (Goodman, 1953), and its association with $\beta$-amyloid and neurofibrillary tangles or with ferritin in peripheral glial cells was also documented (Kim et al., 2018; Mandel et al., 2007; Ward et al., 2014). The level of iron in deep grey matter and the neocortex reported by $3 \mathrm{~T}$ MRI was higher in $\mathrm{AD}$-patients when compared to healthy control subjects (Damulina et al., 2020). Elevated iron in AD-patients is also related to the degree of cognitive impairments (Derry and Kent, 2017). Abnormally increased iron in the brain of AD patients can interact with $\mathrm{H}_{2} \mathrm{O}_{2}$ to produce highly active hydroxyl radicals, which damage cellular structures (Levi and Tiranti, 2019). In AD patients, TFR is reported to be increased in the hippocampus (Morris et al., 1994), although the level of Fpn is reduced in many cerebral regions (Raha et al., 2013), which may indicate the enhanced uptake of iron which accumulates in in neuronal cells. However, the low levels of plasma iron are also reported in AD-patients (Faux et al., 2014; Camaschella, 2013), which may be attributed to the abnormal loading and desaturation of TF (Hare 
et al., 2015). Hence, the relationship between iron overload and AD pathology still requires further research.

Through MRI or quantitative susceptibility mapping (QSM), iron accumulation can also be observed in the motor cortex in ALS (Bhattarai et al., 2020; Ignjatovic et al., 2013). Increased ferritin and the decreased TFR were reported in plasma of ALS patients (Mitchell et al., 2010; Qureshi et al., 2008). Similarly, increases in serum iron, ferritin and saturated TF were found in ALS patients (Veyrat-Durebex et al., 2014); serum ferritin is even considered as a biomarker for ALS progression (Yu et al., 2018). In addition, the level of iron is also increased in the CSF of ALS patients (Hozumi et al., 2011), which may translate into iron-induced oxidative stress and ROS generation (Ignjatovic et al., 2012). Iron overload in the brain may stimulate neuroinflammation by activating TNF- $\alpha$ converting enzyme (Lee et al., 2015). Finally, mutations of genes encoding the regulation related proteins of iron, such as homeostatic iron regulator (HFE) and SLC11A2 (encoding DMT1) genes, have been observed in ALS (Guida et al., 2018; Nandar et al., 2013 and 2014; Blasco et al., 2011).

\subsection{Iron toxicity and neuroglia}

In the CNS, astrocytes accumulate $\mathrm{Fe}^{2+}$ through plasmalemmal transporters DMT1 and ZIP14 (Codazzi et al., 2015; Bishop et al., 2010). Astrocytes can also accumulate $\mathrm{Fe}^{3+}$ bound to TFR, the expression of which was found in cultured astrocytes (Zarruk et al., 2015) and recently confirmed in vivo (Xia et al., 2020). Astrocytes also contribute to maintaining the pool of $\mathrm{Fe}^{2+}$ in the brain by secreting acidic interstitial buffers (Hohnholt et al., 2013; Pelizzoni et al., 2013; Ji and Kosman, 2015). Iron is stored as ferritin in astrocytes and is released by Fpn and the ferroxidase CP (Wu et al., 2004); the deficiency of CP can also lead to the iron overload in the brain and neurotoxicity (Jeong and David, 2003).

In iron-induced chronic seizure models, astrocytic EAAT expression is persistently decreased in the hippocampus, whereas the neuroactive androgen steroid dehydroepiandrosterone can exert an antiepileptic action by up-regulating these transporters (Mishra et al., 2013). With ageing, the permeability of the BBB is increased, and iron deposition is also increased in astrocytes from the cortex, hippocampus and basal ganglia (Farrall and Wardlaw, 2009; Block et al., 2007). However, iron overloaded astrocytes may become a trigger of neurotoxicity that contributes to the pathogenesis of age-dependent neurodegeneration, which involves iron-induced oxidative stress and mitochondrial malfunction (Dringen et al., 2007; Schipper et al., 2009). In the frontal cortex, iron dextran increases the glial fibrillary acidic protein (GFAP)-positive astroglial profiles (Liang et al., 2020), which is indicative of reactive astrogliosis (Fig. 1).

As shown in Fig. 2, the iron overload can impair the brain-wide glymphatic system (Liang et al., 2020), responsible for the clearance of waste proteins through a 
paravascular pathway (Iliff and Nedergaard, 2013). In the mice model of depression induced by chronic unpredictable mild stress (CUMS), the function of glymphatic system is suppressed by down-regulation of the expression of the astrocytic water channel aquaporin 4 (AQP4) (Xia et al., 2016). Injection of iron dextran further worsens the operation of the glymphatic system and exacerbates the depressive-like behaviours induced by CUMS; in turn, this triggers neuronal apoptosis (Liang et al., 2020). Hence, the iron supplements for major depressive patients should be monitored. Coincidentally, iron oxide nanoparticles (widely applied in biological and medical fields) are also reported to cause toxic damage to human astrocytes (Valdiglesias et al., 2016; Coccini et al., 2017).

Microglial cells, responsible for innate brain immunity, are also involved in iron homeostasis. Microglia are the most efficient in accumulating iron as a cell type in the brain, followed by astrocytes, and then neurons (Bishop et al., 2011). However, this may differ between brain regions (Reinert et al., 2019), because expression of iron transporters varies greatly in neural cells from different brain regions (Rouault, 2013). Astrocytes are well known to regulate the transport of iron to other neural cells (Dringen et al., 2007), and microglia supplies iron to oligodendrocytes to ensure their demand of iron (Zhang et al., 2006). Accumulation of iron in microglia gradually increases with age through the elevation of ferritin (Lopes et al., 2008). Ferritin positive dystrophic microglia are associated with $\beta$-amyloid plaques and neuofibrillary tangles (Streit et al. 2014). Aberrant iron homeostasis increases the release of proinflammatory cytokines from microglia in vitro (Wang et al. 2013). Neuromelanin, a protein that stores iron in neurones can be phagocytosed by microglia, which can increase production of proinflammatory cytokines and ROS, thus, exacerbating neurodegeneration (Rathnasamy et al. 2013). Accumulation of iron in microglia is consistently observed in the neurodegeneration-prone brain regions, providing a high correlation between the pathological phenomena of neurodegeneration and the increase of iron in microglia (Andersen et al., 2014).

\section{Conclusion and future directions}

Rising environmental contamination and increased presence of heavy metals in general life along with related neurotoxicity are gaining increasing attention. Astrocytes are key protectors of neurones in the CNS, but under the exposure to excessive heavy metals, astrocytes may become the main targets. Heavy metals, such as $\mathrm{Mn}, \mathrm{Pb}, \mathrm{Hg}$ and iron, all can destroy the integrity of nervous tissue and affect glial-neuronal interactions. In particular, heavy metals severely disrupt glutamate homeostasis through affecting expression and efficacy of glutamate/GABA-glutamine shuttle at multiple levels including suppression of glutamine synthetase activity and down-regulation of plasmalemmal glutamate transporters. Heavy metal-induced glutamate excitotoxicity evokes pathological $\mathrm{Ca}^{2+}$ signalling and damages intracellular $\mathrm{Ca}^{2+}$ homoeostasis, triggers oxidative stress, destroys mitochondria, and instigates cell death. The neurotoxicity caused by heavy metals in astrocytes can play 
a deteriorative role in facilitating neurodegenerative diseases. Among these heavy metals, some are key trace elements for physiological and developmental processes, like iron, so its homoeostasis is essential for proper operation of the CNS. Iron overload in neurodegenerative disorders is widely reported, while MRI images support the accumulation of iron in brains of patients suffering from AD, PD and ALS. Iron-mediated neurotoxicity is also associated with reactive astrogliosis and impairments of th eglymphatic system, which may also contribute to the progression of neurodegenerative diseases.

Future research need to consider several issues:: (i) monitoring of heavy metals in the CNS should receive more attention, especially of the iatrogenic origin; (ii) the reasons for the metals deposition in specific brain regions are little known, although these depositions may directly contribute to the occurrence of neurodegenerative diseases, such as PD; (iii) the ways to effectively reduce the neurotoxicity induced by heavy metals using antioxidants, anti-inflammation agents, and/or by (epi)genetic modulation; (iv) understanding the relationship between the accumulation of heavy metal(s) and brain ageing and whether the effective clearance of excessive metal can slow the ageing process and improve the cognitive longevity.

\section{Acknowledgements}

BL was supported by Grant No. 81871852 from the National Natural Science Foundation of China, Grant No. XLYC1807137 from LiaoNing Revitalization Talents Program, Grant No. 20151098 from the Scientific Research Foundation for Returned Scholars of Education Ministry of China, Grant No. 202078 from Liaoning BaiQianWan Talents Program, and Grant No. 2020703 from "ChunHui" Program of Education Ministry of China. RZ was supported by grants from the Slovenian Research Agency (P3 310, P1-0055, J3 4051, J3 4146, L3 3654; J3 3236, J3 6790, J3 6789, J3 7605). V.P.'s work is supported by a grant from the National Institute of General Medical Sciences of the National Institutes of Health (R01GM123971). VP is an Honorary Professor at University of Rijeka, Croatia. 


\section{References}

Adlard, P. A., Sedjahtera, A., Gunawan, L., Bray, L., Hare, D., Lear, J., Doble, P., Bush, A. I., Finkelstein, D. I., Cherny, R. A., 2014. A novel approach to rapidly prevent age-related cognitive decline. Aging cell 13(2), 351-359. https://doi.org/10.1111/acel.12178.

Al Kahtani M. A., 2020. Effect of both selenium and biosynthesized nanoselenium particles on cadmium-induced neurotoxicity in albino rats. Hum. Exp. Toxicol. 39(2), 159-172. https://doi.org/10.1177/0960327119880589.

Allen, J. W., Mutkus, L. A., Aschner, M., 2001. Methylmercury-mediated inhibition of 3H-D-aspartate transport in cultured astrocytes is reversed by the antioxidant catalase. Brain. Res. 902(1), 92-100. https://doi.org/10.1016/s0006-8993(01)02375-7.

Andersen, H. H., Johnsen, K. B., Moos, T., 2014. Iron deposits in the chronically inflamed central nervous system and contributes to neurodegeneration. Cell Mol Life Sci. 71(9), 1607-1622. https://doi.org/10.1007/s00018-013-1509-8.

Ashraf, A., Clark, M., So, P. W., 2018. The Aging of Iron Man. Front. Aging. Neurosci. 10, 65. https://doi.org/10.3389/fnagi.2018.00065.

Bai, J., Zhao, Q., Wang, W., Wang, X., Jia, J., Cui, B., Liu, X., 2019. Arsenic and heavy metals pollution along a salinity gradient in drained coastal wetland soils: depth distributions, sources and toxic risks. Ecol. Indic. 96, 91-98

Bak, L. K., Schousboe, A., Waagepetersen, H. S., 2006. The glutamate/GABA-glutamine cycle: aspects of transport, neurotransmitter homeostasis and ammonia transfer. J. Neurochem. 98(3), 641-653. https://doi.org/10.1111/j.1471-4159.2006.03913.x.

Basun, H., Forssell, L. G., Wetterberg, L., Winblad, B., 1991. Metals and trace elements in plasma and cerebrospinal fluid in normal aging and Alzheimer's disease. J. Neural. Transm. Park..Dis..Dement. Sect. 3(4), 231-258.

Bauer, E., Toepper, M., Gebhardt, H., Gallhofer, B., Sammer, G., 2015. The significance of caudate volume for age-related associative memory decline. Brain. Res. 1622, 137-148. https://doi.org/10.1016/i.brainres.2015.06.026.

Belaidi, A. A., Bush, A. I., 2016. Iron neurochemistry in Alzheimer's disease and Parkinson's disease: targets for therapeutics. J. Neurochem. 139 Suppl 1, 179-197. https://doi.org/10.1111/jnc.13425.

Berger, U. V., Hediger, M. A., 2000. Distribution of the glutamate transporters GLAST and GLT-1 in rat circumventricular organs, meninges, and dorsal root ganglia. J. Comp. Neurol. 421(3), 385-399. https://doi.org/10.1002/(sici)1096-9861(20000605)421:3<385::aid-cne7>3.0.co;2-s. Bhattarai, A., Chen, Z., Ward, P., Talman, P., Mathers, S., Phan, T. G., Chapman, C., Howe, J., Lee, S., Lie, Y., Egan, G. F., Chua, P., 2020. Serial assessment of iron in the motor cortex in limb-onset amyotrophic lateral sclerosis using quantitative susceptibility mapping. Quant. Imaging. Med. Surg. 10(7), 1465-1476. https://doi.org/10.21037/qims-20-187.

Bishop, G. M., Dang, T. N., Dringen, R., Robinson, S. R., 2011. Accumulation of non-transferrin-bound iron by neurons, astrocytes, and microglia. Neurotox. Res. 19(3), 443-451. https://doi.org/10.1007/s12640-010-9195-x.

Bishop, G. M., Scheiber, I. F., Dringen, R., Robinson, S. R., 2010. Synergistic accumulation of iron and zinc by cultured astrocytes. J. Neural. Transm. (Vienna). 117(7), 809-817. https://doi.org/10.1007/s00702-010-0420-9. 
Bjørklund, G., Hofer, T., Nurchi, V. M., Aaseth, J., 2019. Iron and other metals in the pathogenesis of Parkinson's disease: Toxic effects and possible detoxification. J. Inorg. Biochem. 199, 110717. https://doi.org/10.1016/j.jinorgbio.2019.110717.

Blasco, H., Vourc'h, P., Nadjar, Y., Ribourtout, B., Gordon, P. H., Guettard, Y. O., Camu, W., Praline, J., Meininger, V., Andres, C. R., Corcia, P., French ALS study group 2011. Association between divalent metal transport 1 encoding gene (SLC11A2) and disease duration in amyotrophic lateral sclerosis. J. Neurol. Sci. 303(1-2), 124-127. https://doi.org/10.1016/j.jns.2010.12.018.

Block, M. L., Zecca, L., Hong, J. S., 2007. Microglia-mediated neurotoxicity: uncovering the molecular mechanisms. Nat. Rev. Neurosci. 8(1), 57-69. https://doi.org/10.1038/nrn2038.

Buckner R. L., 2004. Memory and executive function in aging and AD: multiple factors that cause decline and reserve factors that compensate. Neuron. 44(1), 195-208. https://doi.org/10.1016/j.neuron.2004.09.006.

Busche, M. A., Eichhoff, G., Adelsberger, H., Abramowski, D., Wiederhold, K. H., Haass, C., Staufenbiel, M., Konnerth, A., Garaschuk, O., 2008. Clusters of hyperactive neurons near amyloid plaques in a mouse model of Alzheimer's disease. Science. 321(5896), 1686-1689. https://doi.org/10.1126/science.1162844.

Camaschella C., 2013. Iron and hepcidin: a story of recycling and balance. Hematology. Am. Soc. Hematol. Educ. Program. 2013, 1-8. https://doi.org/10.1182/asheducation-2013.1.1.

Carbone, M., Duty, S., Rattray, M., 2012. Riluzole elevates GLT-1 activity and levels in striatal astrocytes. Neurochem. Int. 60(1), 31-38. https://doi.org/10.1016/j.neuint.2011.10.017.

Ceylan, H., Budak, H., Kocpinar, E. F., Baltaci, N. G., Erdogan, O., 2019. Examining the link between dose-dependent dietary iron intake and Alzheimer's disease through oxidative stress in the rat cortex. J. Trace. Elem. Med. Biol. 56, 198-206. https://doi.org/10.1016/j.jtemb.2019.09.002.

Chaudhry, F. A., Lehre, K. P., van Lookeren Campagne, M., Ottersen, O. P., Danbolt, N. C., Storm-Mathisen, J., 1995. Glutamate transporters in glial plasma membranes: highly differentiated localizations revealed by quantitative ultrastructural immunocytochemistry. Neuron. 15(3), 711-720. https://doi.org/10.1016/0896-6273(95)90158-2.

Chen, H., Attieh, Z. K., Su, T., Syed, B. A., Gao, H., Alaeddine, R. M., Fox, T. C., Usta, J., Naylor, C. E., Evans, R. W., McKie, A. T., Anderson, G. J., Vulpe, C. D., 2004. Hephaestin is a ferroxidase that maintains partial activity in sex-linked anemia mice. Blood. 103(10), 3933-3939. https://doi.org/10.1182/blood-2003-09-3139.

Chin-Chan, M., Navarro-Yepes, J., Quintanilla-Vega, B., 2015. Environmental pollutants as risk factors for neurodegenerative disorders: Alzheimer and Parkinson diseases. Front. Cell. Neurosci. 9, 124. https://doi.org/10.3389/fncel.2015.00124.

Choi D. W., 1992. Excitotoxic cell death. J. Neurobiol. 23(9), 1261-1276. https://doi.org/10.1002/neu.480230915.

Cieri, D., Brini, M., Calì, T., 2017. Emerging (and converging) pathways in Parkinson's disease: keeping mitochondrial wellness.Biochem. Biophys. Res. Commun. 483(4), 1020-1030. https://doi.org/10.1016/j.bbrc.2016.08.153.

Coccini, T., Caloni, F., Ramírez Cando, L. J., De Simone, U., 2017. Cytotoxicity and proliferative capacity impairment induced on human brain cell cultures after short- and long-term exposure to magnetite nanoparticles. J. Appl. Toxicol. 37(3), 361-373. https://doi.org/10.1002/jat.3367. 
Codazzi, F., Pelizzoni, I., Zacchetti, D., Grohovaz, F., 2015. Iron entry in neurons and astrocytes: a link with synaptic activity. Front. Mol. Neurosci. 8, 18. https://doi.org/10.3389/fnmol.2015.00018. Corrigan, F. M., Reynolds, G. P., Ward, N. I., 1993. Hippocampal tin, aluminum and zinc in Alzheimer's disease. Biometals. 6(3), 149-154. https://doi.org/10.1007/BF00205853.

Crespo, Â. C., Silva, B., Marques, L., Marcelino, E., Maruta, C., Costa, S., Timóteo, A., Vilares, A., Couto, F. S., Faustino, P., Correia, A. P., Verdelho, A., Porto, G., Guerreiro, M., Herrero, A., Costa, C., de Mendonça, A., Costa, L., Martins, M., 2014. Genetic and biochemical markers in patients with Alzheimer's disease support a concerted systemic iron homeostasis dysregulation. Neurobiol. Aging. 35(4), 777-785. https://doi.org/10.1016/j.neurobiolaging.2013.10.078.

Damulina, A., Pirpamer, L., Soellradl, M., Sackl, M., Tinauer, C., Hofer, E., Enzinger, C., Gesierich, B., Duering, M., Ropele, S., Schmidt, R., Langkammer, C., 2020. Cross-sectional and Longitudinal Assessment of Brain Iron Level in Alzheimer Disease Using 3-T MRI. Radiology 192541. Advance online publication. https://doi.org/10.1148/radiol.2020192541.

Danbolt N. C., 2001. Glutamate uptake. Prog. Neurobiol. 65(1), 1-105. https://doi.org/10.1016/s0301-0082(00)00067-8.

Danysz, W., Parsons, C. G., 2012. Alzheimer's disease, $\beta$-amyloid, glutamate, NMDA receptors and memantine--searching for the connections. Br. J. Pharmacol. 167(2), 324-352. https://doi.org/10.1111/j.1476-5381.2012.02057.x.

Deng, Y., Xu, Z., Xu, B., Xu, D., Tian, Y., Feng, W., 2012. The protective effects of riluzole on manganese-induced disruption of glutamate transporters and glutamine synthetase in the cultured astrocytes. Biol. Trace. Elem. Res. 148(2), 242-249. https://doi.org/10.1007/s12011-012-9365-1.

Derry, P. J., Kent, T. A., 2017. Correlating quantitative susceptibility mapping with cognitive decline in Alzheimer's disease. Brain. 140(8), 2069-2072. https://doi.org/10.1093/brain/awx167.

Dev, S., Babitt, J. L., 2017. Overview of iron metabolism in health and disease. Hemodial. Int. 21 Suppl 1(Suppl 1), S6-S20. https://doi.org/10.1111/hdi.12542.

Dias, V., Junn, E., Mouradian, M. M., 2013. The role of oxidative stress in Parkinson's disease. J. Parkinsons. Dis. 3(4), 461-491. https://doi.org/10.3233/JPD-130230.

Dringen, R., Bishop, G. M., Koeppe, M., Dang, T. N., Robinson, S. R., 2007. The pivotal role of astrocytes in the metabolism of iron in the brain. Neurochem. Res. 32(11), 1884-1890. https://doi.org/10.1007/s11064-007-9375-0.

Działo, J., Tokarz-Deptuła, B., Deptuła, W., 2013. Excitotoxicity and Wallerian degeneration as a processes related to cell death in nervous system. Arch. Ital. Biol. 151(2), 67-75. https://doi.org/10.4449/aib.v151i2.1471.

Eid, A., Mhatre, I., Richardson, J. R., 2019. Gene-environment interactions in Alzheimer's disease: A potential path to precision medicine. Pharmacol. Ther. 199, 173-187. https://doi.org/10.1016/j.pharmthera.2019.03.005.

Erikson, K. M., Aschner, M., 2006. Increased manganese uptake by primary astrocyte cultures with altered iron status is mediated primarily by divalent metal transporter. Neurotoxicology. 27(1), 125-130. https://doi.org/10.1016/j.neuro.2005.07.003.

Farrall, A. J., Wardlaw, J. M., 2009. Blood-brain barrier: ageing and microvascular disease--systematic review and meta-analysis. Neurobiol. Aging. 30(3), 337-352. https://doi.org/10.1016/j.neurobiolaging.2007.07.015.

Faux, N. G., Rembach, A., Wiley, J., Ellis, K. A., Ames, D., Fowler, C. J., Martins, R. N., Pertile, K. K., Rumble, R. L., Trounson, B., Masters, C. L., AIBL Research Group., Bush, A. I., 2014. An 
anemia of Alzheimer's disease. Mol. Psychiatry. 19(11), 1227-1234. https://doi.org/10.1038/mp.2013.178.

Fitsanakis, V. A., Piccola, G., Aschner, J. L., Aschner, M., 2006. Characteristics of manganese (Mn) transport in rat brain endothelial (RBE4) cells, an in vitro model of the blood-brain barrier. Neurotoxicology. 27(1), 60-70. https://doi.org/10.1016/j.neuro.2005.06.004.

Fitsanakis, V. A., Piccola, G., Marreilha dos Santos, A. P., Aschner, J. L., Aschner, M., 2007. Putative proteins involved in manganese transport across the blood-brain barrier. Hum. Exp. Toxicol. 26(4), 295-302. https://doi.org/10.1177/0960327107070496.

Fukushima, T., Tan, X., Luo, Y., Wang, P., Song, J., Kanda, H., Hayakawa, T., Kumagai, T., Kakamu, T., Tsuji, M., Hidaka, T., Mori, Y., 2013. Heavy metals in blood and urine and its relation to depressive symptoms in Parkinson's disease patients. Fukushima. J. Med. Sci. 59(2), 76-80. https://doi.org/10.5387/fms.59.76.

Gerhardsson, L., Lundh, T., Minthon, L., Londos, E., 2008. Metal concentrations in plasma and cerebrospinal fluid in patients with Alzheimer's disease. Dement. Geriatr. Cogn. Disord. 25(6), 508-515. https://doi.org/10.1159/000129365.

Gilbert, M. E., Mack, C. M., Lasley, S. M., 1999. The influence of developmental period of lead exposure on long-term potentiation in the adult rat dentate gyrus in vivo. Neurotoxicology. 20(1), 57-69.

Godfrey, M. E., Wojcik, D. P., Krone, C. A., 2003. Apolipoprotein E genotyping as a potential biomarker for mercury neurotoxicity. J. Alzheimers. Dis. 5(3), 189-195. https://doi.org/10.3233/jad-2003-5303.

Goodman L., 1953. Alzheimer's disease; a clinico-pathologic analysis of twenty-three cases with a theory on pathogenesis. J. Nerv. Ment. Dis. 118(2), 97-130.

Gorell, J. M., Johnson, C. C., Rybicki, B. A., Peterson, E. L., Kortsha, G. X., Brown, G. G., Richardson, R. J., 1997. Occupational exposures to metals as risk factors for Parkinson's disease. Neurology. 48(3), 650-658. https://doi.org/10.1212/wnl.48.3.650.

Grabrucker, A. M., Rowan, M., Garner, C. C., 2011. Brain-Delivery of Zinc-Ions as Potential Treatment for Neurological Diseases: Mini Review. Drug. Deliv. Lett. 1(1), 13-23. https://doi.org/10.2174/2210303111101010013.

Gu, H., Wei, X., Monnot, A. D., Fontanilla, C. V., Behl, M., Farlow, M. R., Zheng, W., Du, Y., 2011. Lead exposure increases levels of $\beta$-amyloid in the brain and CSF and inhibits LRP1 expression in APP transgenic mice. Neurosci. Lett. 490(1), 16-20. https://doi.org/10.1016/j.neulet.2010.12.017.

Gu, M., Owen, A. D., Toffa, S. E., Cooper, J. M., Dexter, D. T., Jenner, P., Marsden, C. D., Schapira, A. H., 1998. Mitochondrial function, GSH and iron in neurodegeneration and Lewy body diseases. J. Neurol. Sci. 158(1), 24-29. https://doi.org/10.1016/s0022-510x(98)00095-1.

Hammond, S. L., Bantle, C. M., Popichak, K. A., Wright, K. A., Thompson, D., Forero, C., Kirkley, K. S., Damale, P. U., Chong, E., Tjalkens, R. B., 2020. NF-кB signaling in astrocytes modulates brain inflammation and neuronal injury following sequential exposure to manganese and MPTP during development and aging. Toxicol. Sci. Advance online publication. https://doi.org/10.1093/toxsci/kfaa115.

Han, J., Yang, X., Chen, X., Li, Z., Fang, M., Bai, B., Tan, D., 2017. Hydrogen sulfide may attenuate methylmercury-induced neurotoxicity via mitochondrial preservation. Chem. Biol. Interact. 263, 66-73. https://doi.org/10.1016/j.cbi.2016.12.020. 
Hancock, S. M., Finkelstein, D. I., Adlard, P. A., 2014. Glia and zinc in ageing and Alzheimer's disease: a mechanism for cognitive decline? Front. Aging. Neurosci. 6, 137. https://doi.org/10.3389/fnagi.2014.00137.

Hare, D. J., Doecke, J. D., Faux, N. G., Rembach, A., Volitakis, I., Fowler, C. J., Grimm, R., Doble, P. A., Cherny, R. A., Masters, C. L., Bush, A. I., Roberts, B. R., 2015. Decreased plasma iron in Alzheimer's disease is due to transferrin desaturation. ACS. Chem. Neurosci. 6(3), 398-402. https://doi.org/10.1021/cn5003557.

He, Y., Thong, P. S., Lee, T., Leong, S. K., Mao, B. Y., Dong, F., Watt, F., 2003. Dopaminergic cell death precedes iron elevation in MPTP-injected monkeys. Free. Radic. Biol. Med. 35(5), 540-547. https://doi.org/10.1016/s0891-5849(03)00385-X.

Hellman, N. E., Gitlin, J. D., 2002. Ceruloplasmin metabolism and function. Annu. Rev. Nutr. 22, 439-458. https://doi.org/10.1146/annurev.nutr.22.012502.114457.

Heneka, M. T., Rodríguez, J. J., Verkhratsky, A., 2010. Neuroglia in neurodegeneration. Brain. Res. Rev. 63(1-2), 189-211. https://doi.org/10.1016/j.brainresrev.2009.11.004.

Hertz L., 2013. The Glutamate-Glutamine (GABA) Cycle: Importance of Late Postnatal Development and Potential Reciprocal Interactions between Biosynthesis and Degradation. Front. Endocrinol (Lausanne). 4, 59. https://doi.org/10.3389/fendo.2013.00059.

Hertz, L., Dringen, R., Schousboe, A., Robinson, S. R., 1999. Astrocytes: glutamate producers for neurons. J. Neurosci. Res. 57(4), 417-428.

Hohnholt, M. C., Dringen, R., 2013. Uptake and metabolism of iron and iron oxide nanoparticles in brain astrocytes. Biochem. Soc. Trans. 41(6), 1588-1592. https://doi.org/10.1042/BST20130114.

Hozumi, I., Hasegawa, T., Honda, A., Ozawa, K., Hayashi, Y., Hashimoto, K., Yamada, M., Koumura, A., Sakurai, T., Kimura, A., Tanaka, Y., Satoh, M., Inuzuka, T., 2011. Patterns of levels of biological metals in CSF differ among neurodegenerative diseases. J. Neurol. Sci. 303(1-2), 95-99. https://doi.org/10.1016/j.jns.2011.01.003.

Hussien, H. M., Abd-Elmegied, A., Ghareeb, D. A., Hafez, H. S., Ahmed, H., El-Moneam, N. A., 2018. Neuroprotective effect of berberine against environmental heavy metals-induced neurotoxicity and Alzheimer's-like disease in rats. Food. Chem. Toxicol. 111, 432-444. https://doi.org/10.1016/j.fct.2017.11.025.

Ignjatović, A., Stević, Z., Lavrnić, D., Nikolić-Kokić, A., Blagojević, D., Spasić, M., Spasojević, I., 2012. Inappropriately chelated iron in the cerebrospinal fluid of amyotrophic lateral sclerosis $\begin{array}{llll}\text { patients. Amyotroph. } & \text { Lateral. } & \text { Scler. } & \text { 357-362), }\end{array}$ https://doi.org/10.3109/17482968.2012.665929.

Ignjatović, A., Stević, Z., Lavrnić, S., Daković, M., Bačić, G., 2013. Brain iron MRI: a biomarker for amyotrophic lateral sclerosis. J. Magn. Reson. Imaging. 38(6), 1472-1479. https://doi.org/10.1002/jmri.24121.

Ijomone, O. M., Miah, M. R., Akingbade, G. T., Bucinca, H., Aschner, M., 2020. Nickel-Induced Developmental Neurotoxicity in C. elegans Includes Cholinergic, Dopaminergic and GABAergic Degeneration, Altered Behaviour, and Increased SKN-1 Activity. Neurotox. Res. 37(4), 1018-1028. https://doi.org/10.1007/s12640-020-00175-3.

Iliff, J. J., Nedergaard, M., 2013. Is there a cerebral lymphatic system? Stroke. 44(6 Suppl 1), S93-S95. https://doi.org/10.1161/STROKEAHA.112.678698.

Jan, A. T., Azam, M., Siddiqui, K., Ali, A., Choi, I., Haq, Q. M., 2015. Heavy Metals and Human 
Health: Mechanistic Insight into Toxicity and Counter Defense System of Antioxidants. Int. J. Mol. Sci. 16(12), 29592-29630. https://doi.org/10.3390/ijms161226183.

Jeong, S. Y., David, S., 2003. Glycosylphosphatidylinositol-anchored ceruloplasmin is required for iron efflux from cells in the central nervous system. J. Biol. Chem. 278(29), 27144-27148. https://doi.org/10.1074/jbc.M301988200.

Ji, C., Kosman, D. J., 2015. Molecular mechanisms of non-transferrin-bound and transferring-bound iron uptake in primary hippocampal neurons. J. Neurochem. 133(5), 668-683. https://doi.org/10.1111/jnc.13040.

Jiang, H., Qian, Z. M., Xie, J. X., 2003. Sheng. Li. Xue. Bao. [Acta physiologica Sinica] 55(5), 571-576.

Jiang, H., Song, N., Jiao, Q., Shi, L., Du, X., 2019. Iron Pathophysiology in Parkinson Diseases. Adv. Exp. Med. Biol. 1173, 45-66. https://doi.org/10.1007/978-981-13-9589-5_4.

Johnson, J., Jr, Pajarillo, E., Taka, E., Reams, R., Son, D. S., Aschner, M., Lee, E., 2018. Valproate and sodium butyrate attenuate manganese-decreased locomotor activity and astrocytic glutamate transporters expression in mice. Neurotoxicology. 64, 230-239. https://doi.org/10.1016/j.neuro.2017.06.007.

Karki, P., Kim, C., Smith, K., Son, D. S., Aschner, M., Lee, E., 2015. Transcriptional Regulation of the Astrocytic Excitatory Amino Acid Transporter 1 (EAAT1) via NF- $\kappa$ B and Yin Yang 1 (YY1). J. Biol. Chem. 290(39), 23725-23737. https://doi.org/10.1074/jbc.M115.649327.

Karki, P., Webb, A., Smith, K., Johnson, J., Jr, Lee, K., Son, D. S., Aschner, M., Lee, E., 2014. Yin Yang 1 is a repressor of glutamate transporter EAAT2, and it mediates manganese-induced decrease of EAAT2 expression in astrocytes. Mol. Cell. Biol. 34(7), 1280-1289. https://doi.org/10.1128/MCB.01176-13.

Kim, A. C., Lim, S., Kim, Y. K., 2018. Metal Ion Effects on A $\beta$ and Tau Aggregation. Int. J. Mol. Sci. 19(1), 128. https://doi.org/10.3390/ijms19010128.

Kim, D. K., Park, J. D., Choi, B. S., 2014. Mercury-induced amyloid-beta (A $\beta$ ) accumulation in the brain is mediated by disruption of $A \beta$ transport. J. Toxicol. Sci. 39(4), 625-635. https://doi.org/10.2131/jts.39.625.

Kirischuk, S., Kettenmann, H., Verkhratsky, A., 2007. Membrane currents and cytoplasmic sodium transients generated by glutamate transport in Bergmann glial cells. Pflugers. Arch. 454(2), 245-252. https://doi.org/10.1007/s00424-007-0207-5.

Kirkley, K. S., Popichak, K. A., Afzali, M. F., Legare, M. E., Tjalkens, R. B., 2017. Microglia amplify inflammatory activation of astrocytes in manganese neurotoxicity. J. Neuroinflammation. 14(1), 99. https://doi.org/10.1186/s12974-017-0871-0.

Krishnamurthy, P., Xie, T., Schuetz, J. D., 2007. The role of transporters in cellular heme and porphyrin homeostasis. Pharmacol. Ther. 114(3), 345-358. https://doi.org/10.1016/j.pharmthera.2007.02.001.

Kuchibhotla, K. V., Goldman, S. T., Lattarulo, C. R., Wu, H. Y., Hyman, B. T., Bacskai, B. J., 2008. Abeta plaques lead to aberrant regulation of calcium homeostasis in vivo resulting in structural and functional disruption of neuronal networks. Neuron. 59(2), 214-225. https://doi.org/10.1016/j.neuron.2008.06.008.

Kwakye, G. F., Jiménez, J. A., Thomas, M. G., Kingsley, B. A., McIIvin, M., Saito, M. A., Korley, E. M., 2019. Heterozygous huntingtin promotes cadmium neurotoxicity and neurodegeneration in striatal cells via altered metal transport and protein kinase $\mathrm{C}$ delta dependent oxidative stress and 
apoptosis $\quad$ signaling $\quad$ mechanisms. $\quad$ Neurotoxicology. $\quad 70, \quad 48-61$. https://doi.org/10.1016/j.neuro.2018.10.012.

Lee, E., Sidoryk-Wegrzynowicz, M., Farina, M., Rocha, J. B., Aschner, M., 2013. Estrogen attenuates manganese-induced glutamate transporter impairment in rat primary astrocytes. Neurotox. Res. 23(2), 124-130. https://doi.org/10.1007/s12640-012-9347-2.

Lee, J. K., Shin, J. H., Gwag, B. J., Choi, E. J., 2015. Iron accumulation promotes TACE-mediated TNF- $\alpha$ secretion and neurodegeneration in a mouse model of ALS. Neurobiol. Dis. 80, 63-69. https://doi.org/10.1016/j.nbd.2015.05.009.

Lehre, K. P., Danbolt, N. C., 1998. The number of glutamate transporter subtype molecules at glutamatergic synapses: chemical and stereological quantification in young adult rat brain. J. Neurosci. 18(21), 8751-8757. https://doi.org/10.1523/JNEUROSCI.18-21-08751.1998.

Levenson, C. W., Tassabehji, N. M., 2007. Role and Regulation of Copper and Zinc Transport Proteins in the Central Nervous System, in: Lajtha, A. (Ed.), Handbook of Neurochemistry and Molecular Neurobiology. New York, Plenum. 257-284.

Levi, S., Tiranti, V., 2019. Neurodegeneration with Brain Iron Accumulation Disorders: Valuable Models Aimed at Understanding the Pathogenesis of Iron Deposition. Pharmaceuticals (Basel). 12(1), 27. https://doi.org/10.3390/ph12010027.

Li, N., Liu, F., Song, L., Zhang, P., Qiao, M., Zhao, Q., Li, W., 2014. The effects of early life Pb exposure on the expression of IL1- $\beta$, TNF- $\alpha$ and A $\beta$ in cerebral cortex of mouse pups. J. Trace. Elem. Med. Biol. 28(1), 100-104. https://doi.org/10.1016/j.jtemb.2013.07.003.

Li, Y., Huang, X., Wang, J., Huang, R., Wan, D., 2020. Regulation of Iron Homeostasis and Related Diseases. Mediators. Inflamm. 2020, 6062094. https://doi.org/10.1155/2020/6062094.

Liang, S., Lu, Y., Li, Z., Li, S., Chen, B., Zhang, M., Chen, B., Ji, M., Gong, W., Xia, M., Verkhratsky, A., Wu, X., Li, B., 2020. Iron Aggravates the Depressive Phenotype of Stressed Mice by Compromising the Glymphatic System. Neurosci. Bull. 10.1007/s12264-020-00539-X. Advance online publication. https://doi.org/10.1007/s12264-020-00539-x.

Liu, C., Liang, M. C., Soong, T. W., 2019. Nitric Oxide, Iron and Neurodegeneration. Front. Neurosci. 13, 114. https://doi.org/10.3389/fnins.2019.00114.

Liu, S., Pan, G., Zhang, Y., Xu, J., Ma, R., Shen, Z., Dong, S., 2019. Risk assessment of soil heavy metals associated with land use variations in the riparian zones of a typical urban river gradient. Ecotoxicol. Environ. Saf. 181, 435-444. https://doi.org/10.1016/j.ecoenv.2019.04.060.

Lopes, K. O., Sparks, D. L., Streit, W. J., 2008. Microglial dystrophy in the aged and Alzheimer's disease brain is associated with ferritin immunoreactivity. Glia. 56(10), 1048-1060. https://doi.org/10.1002/glia.20678.

Lu, C., Meng, Z., He, Y., Xiao, D., Cai, H., Xu, Y., Liu, X., Wang, X., Mo, L., Liang, Z., Wei, X., Ao, Q., Liang, B., Li, X., Tang, S., Guo, S., 2018. Involvement of gap junctions in astrocyte impairment induced by manganese exposure. Brain. Res. Bull. 140, 107-113. https://doi.org/10.1016/j.brainresbull.2018.04.009.

Lu, M., Liu, Y., Shao, M., Tesfaye, G. C., Yang, S., 2020. Associations of Iron Intake, Serum Iron and Serum Ferritin with Bone Mineral Density in Women: The National Health and Nutrition Examination Survey, 2005-2010. Calcif. Tissue. Int. 106(3), 232-238. https://doi.org/10.1007/s00223-019-00627-9.

Mandel, S., Amit, T., Bar-Am, O., Youdim, M. B., 2007. Iron dysregulation in Alzheimer's disease: multimodal brain permeable iron chelating drugs, possessing neuroprotective-neurorescue and 
amyloid precursor protein-processing regulatory activities as therapeutic agents. Prog. Neurobiol. 82(6), 348-360. https://doi.org/10.1016/j.pneurobio.2007.06.001.

Martínez-Ruiz, A., Cadenas, S., Lamas, S., 2011. Nitric oxide signaling: classical, less classical, and nonclassical mechanisms. Free. Radic. Biol. Med. 51(1), 17-29. https://doi.org/10.1016/j.freeradbiomed.2011.04.010.

Mason, L. H., Harp, J. P., Han, D. Y., 2014. Pb neurotoxicity: neuropsychological effects of lead toxicity. Biomed. Res. Int. 2014, 840547. https://doi.org/10.1155/2014/840547.

Mathis, S., Couratier, P., Julian, A., Corcia, P., Le Masson, G., 2017. Current view and perspectives in amyotrophic lateral sclerosis. Neural. Regen. Res. 12(2), 181-184. https://doi.org/10.4103/1673-5374.200794.

McAlpine, D., Araki, S., 1958. Minamata disease: an unusual neurological disorder caused by contaminated fish. Lancet 2(7047), 629-631. https://doi.org/10.1016/s0140-6736(58)90348-9.

Melis, J. P., van Steeg, H., Luijten, M., 2013. Oxidative DNA damage and nucleotide excision repair. Antioxid. Redox. Signal. 18(18), 2409-2419. https://doi.org/10.1089/ars.2012.5036.

Mishra, M., Singh, R., Mukherjee, S., Sharma, D., 2013. Dehydroepiandrosterone's antiepileptic action in $\mathrm{FeCl}$-induced epileptogenesis involves upregulation of glutamate transporters. Epilepsy. Res. 106(1-2), 83-91. https://doi.org/10.1016/j.eplepsyres.2013.06.008.

Mitchell, R. M., Simmons, Z., Beard, J. L., Stephens, H. E., Connor, J. R., 2010. Plasma biomarkers associated with ALS and their relationship to iron homeostasis. Muscle. Nerve. 42(1), 95-103. https://doi.org/10.1002/mus.21625.

Miyata, S., Nakamura, S., Nagata, H., Kameyama, M.,1983. Increased manganese level in spinal cords of amyotrophic lateral sclerosis determined by radiochemical neutron activation analysis. J. Neurol. Sci. 61(2), 283-293. https://doi.org/10.1016/0022-510x(83)90012-6.

Morris, C. M., Candy, J. M., Kerwin, J. M., Edwardson, J. A., 1994. Transferrin receptors in the normal human hippocampus and in Alzheimer's disease. Neuropathol. Appl. Neurobiol. 20(5), 473-477. https://doi.org/10.1111/j.1365-2990.1994.tb00998.x.

Moyano, P., García, J. M., García, J., Anadon, M. J., Naval, M. V., Frejo, M. T., Sola, E., Pelayo, A., Pino, J. D., 2020. Manganese increases A $\beta$ and Tau protein levels through proteasome $20 \mathrm{~S}$ and heat shock proteins 90 and 70 alteration, leading to SN56 cholinergic cell death following single and repeated treatment. Ecotoxicol. Environ. Saf. 203, 110975. Advance online publication. https://doi.org/10.1016/j.ecoenv.2020.110975.

Mu, M. D., Qian, Z. M., Yang, S. X., Rong, K. L., Yung, W. H., Ke, Y., 2020. Therapeutic effect of a histone demethylase inhibitor in Parkinson's disease. Cell. Death. Dis. 11(10), 927. https://doi.org/10.1038/s41419-020-03105-5.

Mutkus, L., Aschner, J. L., Syversen, T., Aschner, M., 2005. Methylmercury alters the in vitro uptake of glutamate in GLAST- and GLT-1-transfected mutant CHO-K1 cells. Biol. Trace. Elem. Res. 107(3), 231-245. https://doi.org/10.1385/BTER:107:3:231.

Nandar, W., Connor, J. R., 2011. HFE gene variants affect iron in the brain. J. Nutr. 141(4), 729S-739S. https://doi.org/10.3945/jn.110.130351.

Nandar, W., Neely, E. B., Simmons, Z., Connor, J. R., 2014. H63D HFE genotype accelerates disease progression in animal models of amyotrophic lateral sclerosis. Biochim. Biophys. Acta. 1842(12 Pt A), 2413-2426. https://doi.org/10.1016/j.bbadis.2014.09.016.

Nandar, W., Neely, E. B., Unger, E., Connor, J. R., 2013. A mutation in the HFE gene is associated with altered brain iron profiles and increased oxidative stress in mice. Biochim. Biophys. Acta. 
1832(6), 729-741. https://doi.org/10.1016/j.bbadis.2013.02.009.

Neal, M., Richardson, J. R., 2018. Epigenetic regulation of astrocyte function in neuroinflammation and neurodegeneration. Biochim. Biophys. Acta. Mol. Basis. Dis. 1864(2), 432-443. https://doi.org/10.1016/j.bbadis.2017.11.004.

Nolte, C., Gore, A., Sekler, I., Kresse, W., Hershfinkel, M., Hoffmann, A., Kettenmann, H., Moran, A., 2004. ZnT-1 expression in astroglial cells protects against zinc toxicity and slows the accumulation of intracellular zinc. Glia 48(2), 145-155. https://doi.org/10.1002/glia.20065.

Norenberg, M. D., Martinez-Hernandez, A., 1979. Fine structural localization of glutamine synthetase in astrocytes of rat brain. Brain. Res. 161(2), 303-310. https://doi.org/10.1016/0006-8993(79)90071-4.

Nriagu J. O., 1983. Saturnine gout among Roman aristocrats. Did lead poisoning contribute to the fall of the Empire? N. Engl. J. Med. 308(11), 660-663. https://doi.org/10.1056/NEJM198303173081123.

O'Carroll, R. E., Masterton, G., Dougall, N., Ebmeier, K. P., Goodwin, G. M., 1995. The neuropsychiatric sequelae of mercury poisoning. The Mad Hatter's disease revisited. Br. J. Psychiatry. 167(1), 95-98. https://doi.org/10.1192/bjp.167.1.95.

Okereafor, U., Makhatha, M., Mekuto, L., Uche-Okereafor, N., Sebola, T., Mavumengwana, V., 2020. Toxic Metal Implications on Agricultural Soils, Plants, Animals, Aquatic life and Human Health. Int J Environ Res Public Health. 17(7), 2204. https://doi.org/10.3390/ijerph17072204.

Olivieri, G., Brack, C., Müller-Spahn, F., Stähelin, H. B., Herrmann, M., Renard, P., Brockhaus, M., Hock, C., 2000. Mercury induces cell cytotoxicity and oxidative stress and increases beta-amyloid secretion and tau phosphorylation in SHSY5Y neuroblastoma cells. J. Neurochem. 74(1), 231-236. https://doi.org/10.1046/j.1471-4159.2000.0740231.x.

Olloquequi, J., Cornejo-Córdova, E., Verdaguer, E., Soriano, F. X., Binvignat, O., Auladell, C., Camins, A., 2018. Excitotoxicity in the pathogenesis of neurological and psychiatric disorders: Therapeutic implications. J. Psychopharmacol. 32(3), 265-275. https://doi.org/10.1177/0269881118754680.

Pamphlett, R., Kum Jew, S., 2018. Inorganic mercury in human astrocytes, oligodendrocytes, corticomotoneurons and the locus ceruleus: implications for multiple sclerosis, neurodegenerative disorders and gliomas. Biometals 31(5), 807-819. https://doi.org/10.1007/s10534-018-0124-4.

Paoletti, P., Vergnano, A. M., Barbour, B., Casado, M., 2009. Zinc at glutamatergic synapses. Neuroscience 158(1), 126-136. https://doi.org/10.1016/j.neuroscience.2008.01.061.

Pelizzoni, I., Zacchetti, D., Campanella, A., Grohovaz, F., Codazzi, F., 2013. Iron uptake in quiescent and inflammation-activated astrocytes: a potentially neuroprotective control of iron burden. Biochim Biophys $\quad$ Acta. 1326-1333. https://doi.org/10.1016/j.bbadis.2013.04.007.

Peng, T. I., Jou, M. J., 2010. Oxidative stress caused by mitochondrial calcium overload. Ann. N.Y. Acad. Sci. 1201, 183-188. https://doi.org/10.1111/j.1749-6632.2010.05634.x.

Peres, T. V., Eyng, H., Lopes, S. C., Colle, D., Gonçalves, F. M., Venske, D. K., Lopes, M. W., Ben, J., Bornhorst, J., Schwerdtle, T., Aschner, M., Farina, M., Prediger, R. D., Leal, R. B., 2015. Developmental exposure to manganese induces lasting motor and cognitive impairment in rats. Neurotoxicology. 50, 28-37. https://doi.org/10.1016/j.neuro.2015.07.005.

Powers, K. M., Smith-Weller, T., Franklin, G. M., Longstreth, W. T., Jr, Swanson, P. D., Checkoway, H., 2003. Parkinson's disease risks associated with dietary iron, manganese, and other 
$\begin{array}{llll}\text { nutrient } & \text { intakes. } & \text { Neurology. } & \text { 60(11), }\end{array}$ https://doi.org/10.1212/01.wnl.0000068021.13945.7f.

Qian, Z. M., Ke, Y., 2019. Brain iron transport. Biol. Rev. Camb. Philos. Soc. 94(5), 1672-1684. https://doi.org/10.1111/brv.12521.

Qian, Z. M., Wang, Q., 1998. Expression of iron transport proteins and excessive iron accumulation in the brain in neurodegenerative disorders. Brain. Res. Brain. Res. Rev. 27(3), 257-267. https://doi.org/10.1016/s0165-0173(98)00012-5.

Qu, C. S., Ma, Z. W., Yang, J., Liu, Y., Bi, J., Huang, L., 2012. Human exposure pathways of heavy metals in a lead-zinc mining area, Jiangsu Province, China. PLoS. One. 7(11), e46793. https://doi.org/10.1371/journal.pone.0046793.

Qu, M., Nan, X., Gao, Z., Guo, B., Liu, B., Chen, Z., 2013. Protective effects of lycopene against methylmercury-induced neurotoxicity in cultured rat cerebellar granule neurons. Brain. Res. 1540, 92-102. https://doi.org/10.1016/j.brainres.2013.10.005.

Qureshi, M., Brown, R. H., Jr, Rogers, J. T., Cudkowicz, M. E., 2008. Serum ferritin and metal levels as risk factors for amyotrophic lateral sclerosis. Open. Neurol. J. 2, 51-54. https://doi.org/10.2174/1874205X00802010051.

Raha, A. A., Vaishnav, R. A., Friedland, R. P., Bomford, A., Raha-Chowdhury, R., 2013. The systemic iron-regulatory proteins hepcidin and ferroportin are reduced in the brain in Alzheimer's disease. Acta. Neuropathol. Commun. 1, 55. https://doi.org/10.1186/2051-5960-1-55.

Rahman, A., Al-Qenaie, S., Rao, M. S., Khan, K. M., Guillemin, G. J., 2019. Memantine Is Protective against Cytotoxicity Caused by Lead and Quinolinic Acid in Cultured Rat Embryonic Hippocampal Cells. Chem. Res. Toxicol. 32(6), 1134-1143. https://doi.org/10.1021/acs.chemrestox.8b00421.

Rahman, M. A., Rahman, M. M., Reichman, S. M., Lim, R. P., Naidu, R., 2014. Heavy metals in Australian grown and imported rice and vegetables on sale in Australia: health hazard. Ecotoxicol. Environ. Saf. 100, 53-60. https://doi.org/10.1016/j.ecoenv.2013.11.024

Ramos, P., Santos, A., Pinto, N. R., Mendes, R., Magalhães, T., Almeida, A., 2014. Iron levels in the human brain: a post-mortem study of anatomical region differences and age-related changes. J. Trace. Elem. Med. Biol. 28(1), 13-17. https://doi.org/10.1016/j.jtemb.2013.08.001.

Rathnasamy, G., Ling, E. A., Kaur, C., 2013. Consequences of iron accumulation in microglia and its implications in neuropathological conditions. CNS Neurol. Disord. Drug. Targets. 12(6), 785-798. https://doi.org/10.2174/18715273113126660169.

Rauen, T., Rothstein, J. D., Wässle, H., 1996. Differential expression of three glutamate transporter subtypes in the rat retina. Cell. Tissue. Res. 286(3), 325-336. https://doi.org/10.1007/s004410050702.

Reed, J. C., Pellecchia, M., 2012. Ironing out cell death mechanisms. Cell. 149(5), 963-965. https://doi.org/10.1016/j.cell.2012.05.009.

Reinert, A., Morawski, M., Seeger, J., Arendt, T., Reinert, T., 2019. Iron concentrations in neurons and glial cells with estimates on ferritin concentrations. BMC Neurosci. 20(1), 25. https://doi.org/10.1186/s12868-019-0507-7.

Rose, C. F., Verkhratsky, A., Parpura, V., 2013. Astrocyte glutamine synthetase: pivotal in health and disease. Biochem. Soc. Trans. 41(6), 1518-1524. https://doi.org/10.1042/BST20130237.

Rostoker, G., Vaziri, N. D., 2017. Iatrogenic iron overload and its potential consequences in patients on hemodialysis. Presse. Med. 46(12 Pt 2), e312-e328. 
https://doi.org/10.1016/j.lpm.2017.10.014.

Rostoker, G., Vaziri, N. D., 2017. Impact of iatrogenic iron overload on the course of hepatitis C in the dialysis population: A plea for caution. Hemodial. Int. International Symposium on Home Hemodialysis, 21 Suppl 1, S68-S77. https://doi.org/10.1111/hdi.12557.

Rouault T. A., 2013. Iron metabolism in the CNS: implications for neurodegenerative diseases. Nat. Rev. Neurosci. 14(8), 551-564. https://doi.org/10.1038/nrn3453.

Sarah, R., Tabassum, B., Idrees, N., Hashem, A., Abd Allah, E. F., 2019. Bioaccumulation of heavy metals in Channa punctatus (Bloch) in river Ramganga (U.P.), India. Saudi. J. Biol. Sci. 26(5), 979-984. https://doi.org/10.1016/j.sjbs.2019.02.009.

Schipper, H. M., Song, W., Zukor, H., Hascalovici, J. R., Zeligman, D., 2009. Heme oxygenase-1 and neurodegeneration: expanding frontiers of engagement. J. Neurochem. 110(2), 469-485. https://doi.org/10.1111/j.1471-4159.2009.06160.x.

Schousboe, A., Scafidi, S., Bak, L. K., Waagepetersen, H. S., McKenna, M. C., 2014. Glutamate metabolism in the brain focusing on astrocytes. Adv. Neurobiol. 11, 13-30. https://doi.org/10.1007/978-3-319-08894-5_2.

Shank, R. P., Bennett, G. S., Freytag, S. O., Campbell, G. L., 1985. Pyruvate carboxylase: an astrocyte-specific enzyme implicated in the replenishment of amino acid neurotransmitter pools. Brain. Res. 329(1-2), 364-367. https://doi.org/10.1016/0006-8993(85)90552-9.

Shayeghi, M., Latunde-Dada, G. O., Oakhill, J. S., Laftah, A. H., Takeuchi, K., Halliday, N., Khan, Y., Warley, A., McCann, F. E., Hider, R. C., Frazer, D. M., Anderson, G. J., Vulpe, C. D., Simpson, R. J., McKie, A. T., 2005. Identification of an intestinal heme transporter. Cell. 122(5), 789-801. https://doi.org/10.1016/j.cell.2005.06.025.

Sidoryk-Wegrzynowicz, M., Aschner, M., 2013. Manganese toxicity in the central nervous system: the glutamine/glutamate- $\gamma$-aminobutyric acid cycle. J. Intern. Med. 273(5), 466-477. https://doi.org/10.1111/joim.12040.

Sominsky, L., Walker, A. K., Hodgson, D. M., 2015. Editorial: Neuroinflammation and behavior. Front. Neurosci. 9, 201. https://doi.org/10.3389/fnins.2015.00201.

Stephenson, E., Nathoo, N., Mahjoub, Y., Dunn, J. F., Yong, V. W., 2014. Iron in multiple sclerosis: roles in neurodegeneration and repair. Nat. Rev. Neurol. 10(8), 459-468. https://doi.org/10.1038/nrneurol.2014.118.

Streit, W. J., Xue, Q. S., Tischer, J., Bechmann, I., 2014. Microglial pathology. A Acta Neuropathol. Commun. 2, 142. https://doi.org/10.1186/s40478-014-0142-6.

Struzyńska, L., Chalimoniuk, M., Sulkowski, G., 2005. Changes in expression of neuronal and glial glutamate transporters in lead-exposed adult rat brain. Neurochem. Int. 47(5), 326-333. https://doi.org/10.1016/j.neuint.2005.05.005.

Sudhakaran, S., Athira, S. S., Mohanan, P. V., 2019. Zinc oxide nanoparticle induced neurotoxic potential upon interaction with primary astrocytes. Neurotoxicology. 73, 213-227. https://doi.org/10.1016/j.neuro.2019.04.008.

Sun, X. Y., Wei, Y. P., Xiong, Y., Wang, X. C., Xie, A. J., Wang, X. L., Yang, Y., Wang, Q., Lu, Y. M., Liu, R., Wang, J. Z., 2012. Synaptic released zinc promotes tau hyperphosphorylation by inhibition of protein phosphatase 2A (PP2A). J. Biol. Chem. 287(14), 11174-11182. https://doi.org/10.1074/jbc.M111.309070.

Supino-Viterbo, V., Sicard, C., Risvegliato, M., Rancurel, G., Buge, A., 1977. Toxic encephalopathy due to ingestion of bismuth salts: clinical and EEG studies of 45 patients. J. 
Neurol. Neurosurg. Psychiatry. 40(8), 748-752. https://doi.org/10.1136/jnnp.40.8.748.

Surmeier, D. J., Schumacker, P. T., Guzman, J. D., Ilijic, E., Yang, B., Zampese, E., 2017. Calcium and Parkinson's disease. Biochem. Biophys. Res. Commun. 483(4), 1013-1019. https://doi.org/10.1016/j.bbrc.2016.08.168.

Thomas, G., Leyland, L. A., Schrag, A. E., Lees, A. J., Acosta-Cabronero, J., Weil, R. S., 2020. Brain iron deposition is linked with cognitive severity in Parkinson's disease. J. Neurol. Neurosurg. Psychiatry. 91(4), 418-425. https://doi.org/10.1136/jnnp-2019-322042.

Tian, Z. Y., Wang, C. Y., Wang, T., Li, Y. C., Wang, Z. Y., 2019. Glial S100A6 Degrades $\beta$-amyloid Aggregation through Targeting Competition with Zinc Ions. Aging. Dis. 10(4), 756-769. https://doi.org/10.14336/AD.2018.0912.

Troadec, M. B., Ward, D. M., Lo, E., Kaplan, J., De Domenico, I., 2010. Induction of FPN1 transcription by MTF-1 reveals a role for ferroportin in transition metal efflux. Blood. 116(22), 4657-4664. https://doi.org/10.1182/blood-2010-04-278614.

Ulla, M., Bonny, J. M., Ouchchane, L., Rieu, I., Claise, B., Durif, F., 2013. Is R2* a new MRI biomarker for the progression of Parkinson's disease? A longitudinal follow-up. PloS. one. 8(3), e57904. https://doi.org/10.1371/journal.pone.0057904.

Valdiglesias, V., Fernández-Bertólez, N., Kiliç, G., Costa, C., Costa, S., Fraga, S., Bessa, M. J., Pásaro, E., Teixeira, J. P., Laffon, B., 2016. Are iron oxide nanoparticles safe? Current knowledge and future perspectives. J. Trace. Elem. Med. Biol. 38, 53-63. https://doi.org/10.1016/j.jtemb.2016.03.017.

Verkhratsky, A., Nedergaard, M., 2014. Astroglial cradle in the life of the synapse. Philos. Trans. R. Soc. Lond. B. Biol. Sci. 369(1654), 20130595. https://doi.org/10.1098/rstb.2013.0595.

Verkhratsky, A., Nedergaard, M., 2018. Physiology of Astroglia. Physiol. Rev. 98(1), 239-389. https://doi.org/10.1152/physrev.00042.2016.

Verkhratsky, A., Rose, C. R., 2020. $\mathrm{Na}^{+}$-dependent transporters: The backbone of astroglial homeostatic function. Cell calcium 85, 102136. https://doi.org/10.1016/j.ceca.2019.102136.

Veyrat-Durebex, C., Corcia, P., Mucha, A., Benzimra, S., Mallet, C., Gendrot, C., Moreau, C., Devos, D., Piver, E., Pagès, J. C., Maillot, F., Andres, C. R., Vourc'h, P., Blasco, H., 2014. Iron metabolism disturbance in a French cohort of ALS patients. Biomed. Res. Int. 2014, 485723. https://doi.org/10.1155/2014/485723.

Vogel, C. F., Charrier, J. G., Wu, D., McFall, A. S., Li, W., Abid, A., Kennedy, I. M., Anastasio, C., 2016. Physicochemical properties of iron oxide nanoparticles that contribute to cellular ROS-dependent signaling and acellular production of hydroxyl radical. Free. Radic. Res. 50(11), 1153-1164. https://doi.org/10.3109/10715762.2016.1152360.

Waldron H. A., 1973. Lead poisoning in the ancient world. Med. Hist. 17(4), 391-399. https://doi.org/10.1017/s0025727300019013.

Wan D., Wu Q., Ni H., Liu G., Ruan Z., Yin Y., 2019. Treatments for Iron Deficiency (ID): Prospective Organic Iron Fortification. Curr. Pharm. Des. 25(3), 325-332. https://doi.org/10.2174/1381612825666190319111437.

Wang, J., Song, N., Jiang, H., Wang, J., Xie, J., 2013. Pro-inflammatory cytokines modulate iron regulatory protein 1 expression and iron transportation through reactive oxygen/nitrogen species production in ventral mesencephalic neurons. Biochim. Biophys. Acta. 1832(5), 618-625. https://doi.org/10.1016/j.bbadis.2013.01.021.

Wang, J., Xu, H. M., Yang, H. D., Du, X. X., Jiang, H., Xie, J. X., 2009. Rg1 reduces nigral iron 
levels of MPTP-treated C57BL6 mice by regulating certain iron transport proteins. Neurochem. Int. 54(1), 43-48. https://doi.org/10.1016/j.neuint.2008.10.003.

Wang, S., Wu, W., Liu, F., Liao, R., Hu, Y., 2017. Accumulation of heavy metals in soil-crop systems: a review for wheat and corn. Environ Sci Pollut. Res. Int. 24(18), 15209-15225. https://doi.org/10.1007/s11356-017-8909-5.

Wang, S., Zhao, M., Zhou, M., Li, Y. C., Wang, J., Gao, B., Sato, S., Feng, K., Yin, W., Igalavithana, A. D., Oleszczuk, P., Wang, X., Ok, Y. S., 2019. Biochar-supported nZVI (nZVI/BC) for contaminant removal from soil and water: A critical review. J. Hazard. Mater. 373, 820-834. https://doi.org/10.1016/j.jhazmat.2019.03.080.

Ward, R. J., Zucca, F. A., Duyn, J. H., Crichton, R. R., Zecca, L., 2014. The role of iron in brain ageing and neurodegenerative disorders. Lancet. Neurol. 13(10), 1045-1060. https://doi.org/10.1016/S1474-4422(14)70117-6.

Wieler, M., Gee, M., Martin, W. R., 2015. Longitudinal midbrain changes in early Parkinson's disease: iron content estimated from R2*/MRI. Parkinsonism. Relat. Disord. 21(3), 179-183. https://doi.org/10.1016/j.parkreldis.2014.11.017.

Wu, L. J., Leenders, A. G., Cooperman, S., Meyron-Holtz, E., Smith, S., Land, W., Tsai, R. Y., Berger, U. V., Sheng, Z. H., Rouault, T. A., 2004. Expression of the iron transporter ferroportin in synaptic vesicles and the blood-brain barrier. Brain. Res. 1001(1-2), 108-117. https://doi.org/10.1016/j.brainres.2003.10.066.

Wu, M. L., Deng, J. F., Lin, K. P., Tsai, W. J., 2013. Lead, mercury, and arsenic poisoning due to topical use of traditional Chinese medicines. Am. J. Med. 126(5), 451-454. https://doi.org/10.1016/j.amjmed.2013.01.001.

Xia, M., Guan, W., Ji, M., Li, S., Li, Z., Chen, B., Zhang, M., Liang, S., Chen, B., Gong, W., Dong, C., Wen, G., Zhan, X., Zhang, D., Li, X., Verkhratsky, A., Li, B., 2020. Astrocytes express DMT1 and transferrin receptors, which transport iron thus activating $\mathrm{Ca}^{2+}$ signalling: possible role in neuroprotection against iron overload? BioRxiv 2020.07.06.190652. https://doi.org/10.1101/2020.07.06.190652.

Xia, M., Liang, S., Li, S., Li, Z., Zhang, M., Chen, B., Dong, C., Chen, B., Ji, M., Gong, W., Guan, D., Verkhratsky, A., Li, B., 2020. Iatrogenic Iron Promotes Neurodegeneration and Activates Self-protection of Neural Cells against Exogenous Iron Attacks. BioRxiv. 2020.03.21.001925. https://doi.org/10.1101/2020.03.21.001925.

Xia, M., Yang, L., Sun, G., Qi, S., Li, B., 2017. Mechanism of depression as a risk factor in the development of Alzheimer's disease: the function of AQP4 and the glymphatic $\begin{array}{llll}\text { system. Psychopharmacology } & \text { (Berl). } & \text { 365-379. }\end{array}$ https://doi.org/10.1007/s00213-016-4473-9.

Youdim M. B., 2003. What have we learnt from CDNA microarray gene expression studies about the role of iron in MPTP induced neurodegeneration and Parkinson's disease? J. Neural. Transm. Suppl. 65, 73-88. https://doi.org/10.1007/978-3-7091-0643-3_5.

Yu, J., Wang, N., Qi, F., Wang, X., Zhu, Q., Lu, Y., Zhang, H., Che, F., Li, W., 2018. Serum ferritin is a candidate biomarker of disease aggravation in amyotrophic lateral sclerosis. Biomed. Rep. 9(4), 333-338. https://doi.org/10.3892/br.2018.1138.

Zarruk, J. G., Berard, J. L., Passos dos Santos, R., Kroner, A., Lee, J., Arosio, P., David, S., 2015. Expression of iron homeostasis proteins in the spinal cord in experimental autoimmune encephalomyelitis and their implications for iron accumulation. Neurobiol. Dis. 81, 93-107. 
https://doi.org/10.1016/j.nbd.2015.02.001.

Zhang, F., Xing, S., Li, Z., 2017. Antagonistic effects of lycopene on cadmium-induced hippocampal dysfunctions in autophagy, calcium homeostatis and redox. Oncotarget 8(27), 44720-44731. https://doi.org/10.18632/oncotarget.18249.

Zhang, X., Surguladze, N., Slagle-Webb, B., Cozzi, A., Connor, J. R., 2006. Cellular iron status influences the functional relationship between microglia and oligodendrocytes. Glia. 54(8), 795-804. https://doi.org/10.1002/glia.20416.

Zhang, Y., Wan, D., Zhou, X., Long, C., Wu, X., Li, L., He, L., Huang, P., Chen, S., Tan, B., Yin, Y., 2017. Diurnal variations in iron concentrations and expression of genes involved in iron absorption and metabolism in pigs. Biochem. Biophys. Res. Commun. 490(4), 1210-1214. https://doi.org/10.1016/j.bbrc.2017.06.187.

Zhao, F., Liao, Y., Jin, Y., Li, G., Lv, X., Sun, G., 2012. Effects of arsenite on glutamate metabolism in primary cultured astrocytes. Toxicol. In. Vitro. 26(1), 24-31. https://doi.org/10.1016/j.tiv.2011.10.003.

Zheng, Z., White, C., Lee, J., Peterson, T. S., Bush, A. I., Sun, G. Y., Weisman, G. A., Petris, M. J., 2010. Altered microglial copper homeostasis in a mouse model of Alzheimer's disease. J. Neurochem. 114(6), 1630-1638. https://doi.org/10.1111/j.1471-4159.2010.06888.x.

Zhou, Y., Danbolt, N. C., 2013. GABA and Glutamate Transporters in Brain. Front. Endocrinol. 4, 165. https://doi.org/10.3389/fendo.2013.00165. 


\section{Figure Legends}

Figure 1. 3D-images of GFAP labelled astrocytes in frontal cortex.

After treatment with dextran (control) or $2 \mathrm{mg} / \mathrm{kg} / \mathrm{day}$ iron dextran for 6 days, 3D-images of GFAP residing in astrocytes were taken in the mouse frontal cortex indicating a development of reactive astrogliosis.

Figure 2. Excess iron aggravates malfunction of glymphatic system in chronic unpredictable mild stress-treated mice.

(A, B) Mice were pre-treated with or without chronic unpredictable mild stress (CUMS) for 6 weeks; in the last week the mice were randomly separated to be injected with dextran or iron dextran for 6 days. The fluorescence tracer (OA555, $45 \mathrm{kDa}$ ) was injected intracisternally. (A) Representative images indicated the fluorescence tracer penetration into the brain; OA555 (red) and DAPI (blue; cell nuclei label) were stained simultaneously, in anterior and posterior brain slices. Scale bar, $1 \mathrm{~mm}$. (B) Thirty minutes after injection, the animals were perfusion fixed and the whole-slice fluorescence was calculated. The fluorescence intensities of OA555 normalised to the intensity of the control group were assessed. Scale bar, $50 \mu \mathrm{m}$. Data are presented as mean $\pm \mathrm{SEM}, \mathrm{n}=6 .{ }^{*} \mathrm{p}<0.05$, statistically significant difference compared to the control group. ${ }^{*} \mathrm{p}<0.05$, statistically significant difference compared to any other group. (Reproduced from Liang et al., 2020 with permission). 

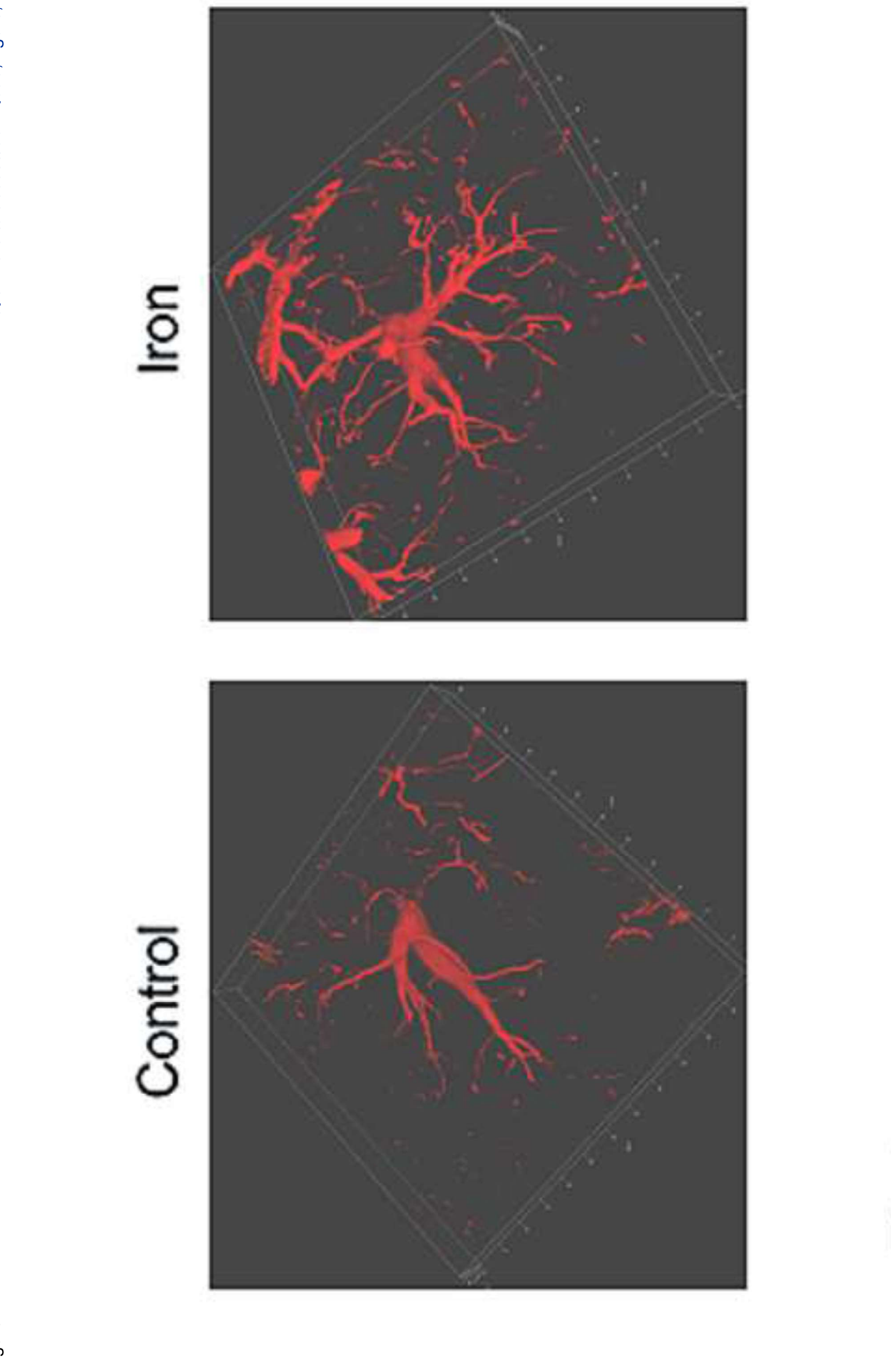

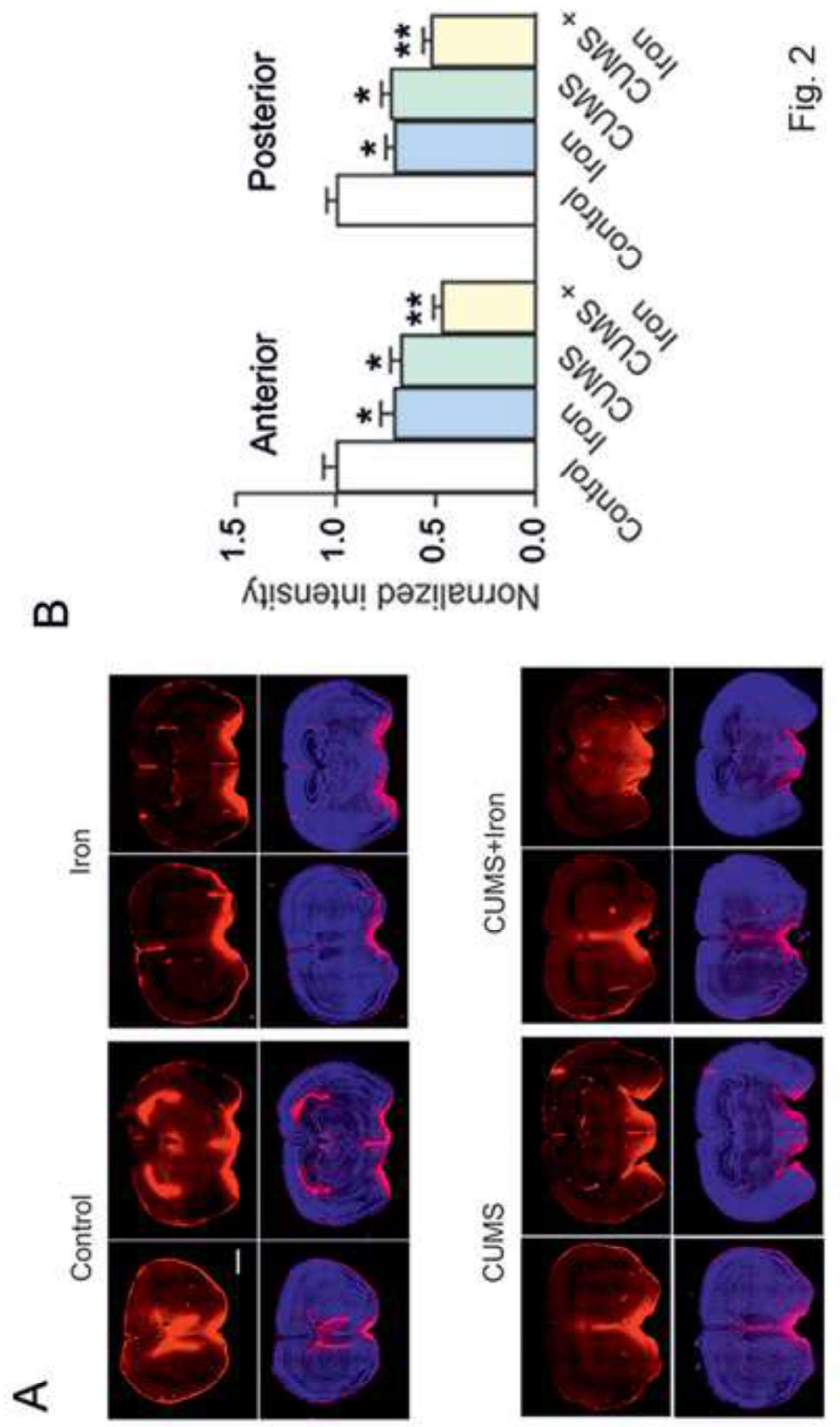

N
$\stackrel{0}{5}$
은 